Yll: 2019, Cilt: 52, Sayl: 3, 801-836

DOI: 10.30964/auebfd.466469, E-ISSN: 2458-8342, P-ISSN: 1301-3718

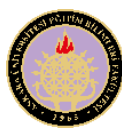

\title{
Aday Öğretmen Yetiştirme Programının Etkililiğine İlişkin Aday ve Danışman Öğretmen Görüsşlerinin Değerlendirilmesi ${ }^{1}$
}

\begin{tabular}{lccc}
\hline MAKALE TÜRÜ & Başvuru Tarihi & Kabul Tarihi & Yayın Tarihi \\
Araştırma Makalesi & 02.10 .2018 & 04.10 .2019 & 04.10 .2019 \\
\hline
\end{tabular}

\author{
Abdurrahman Ekinci (iD) ${ }^{2}$, Serdar Bozan (iD ${ }^{3}$ ve Halis Sakız (iD ${ }^{4}$ \\ Mardin Artuklu Üniversitesi
}

Öz

$\mathrm{Bu}$ araştırmanın amacı, aday öğretmen yetiştirme programının etkililiğini aday ve danışman öğretmen görüşleri ışığında belirleyerek sürece ilişkin önerilerde bulunmaktır. Çalışma grubunu 2015-2016 öğretim yılında Mardin ili Artuklu, Kızıltepe, Ömerli, Yeşilli, Nusaybin ilçe sınırları içerisinde bulunan anaokulu, ilkokul, ortaokul ve ortaöğretim okullarına atanan 207 aday öğretmen ve aday öğretmenlere görevlendirilen 179 danışman öğretmen oluşturmuştur. Araştırmada karma araştırma yöntemi kullanılmış, toplanan veriler karma araştırma modeli ile bir araya getirerek yorumlanmıştır. Nicel verilerin toplanmasında araștırmacılar tarafından aday ve danıșman öğretmenler için ayrı geliștirilen "aday ve danıșman öğretmen ölçekleri”, nitel verilerin toplanmasında ise benzer şekilde araştırmacılar tarafindan geliştirilen yarı yapılandırılmış görüşme formları kullanılmıştır. Nicel verilerin istatistiksel çözümlenmesinde, t- testi ve ANOVA teknikleri kullanılmıştır. Nitel verilere, içerik analizi uygulanarak yorumlanmıştır. Nicel bulgular, aday öğretmenlerin programın etkililiğine dair çoğunlukla kararsız, danışmanların ise programdan memnun olduğunu göstermektedir. Nitel verilerden elde edilen bulgular değerlendirildiğinde programın öğretmenliğe yeni atanmış adaylar için çok yararlı bir program olduğu yönündedir.

Anahtar sözcükler: Aday öğretmen, danışman öğretmen, aday öğretmenlik programı.

${ }^{1} \mathrm{Bu}$ çalışmanın nitel bulguları 13-15 Ekim 2016 tarihinde Antalya'da düzenlenen VIII. Denetim kongresinde bildiri olarak sunulmuştur.

${ }^{2}$ Prof. Dr., Edebiyat Fakültesi, Eğitim Bilimleri Bölümü, Eğitim Yönetimi, Teftişi Planlaması ve Ekonomisi Anabilim Dal, E-posta: a.ekinci74@yahoo.com, https://orcid.org/0000-0002-1545-1379

${ }^{3}$ Sorumlu Yazar: Öğr. Gör., Mardin Midyat Meslek Yüksekokulu, Çocuk Gelişimi Bölümü, E-posta: s.bozan@ hotmail.com, https://orcid.org/0000-0002-1677-4727

${ }^{4}$ Doç. Dr., Edebiyat Fakültesi, Psikoloji Bölümü, Gelişim Psikolojisi Anabilim Dalı, E-posta: halissakiz@artuklu.edu.tr, https://orcid.org/0000-0003-2406-1011 
Eğitim sisteminin niteliğini belirleyen önemli konulardan birinin öğretmen niteliği olduğunu söylemek olanaklıdır. $\mathrm{Bu}$ bakımdan ilgili alanyazın ve uygulamalarda öğretmenlerin hizmet öncesi ve hizmet içi süreçte yetiştirilmesi hususu güncelliğini koruyan temel alanlardan biri olmuştur. Özellikle, mesleğin ilk yıllarını oluşturan adaylık süreci, kuramın uygulamayla buluştuğu önemli bir dönemdir. Bu dönemde geçirilen nitelikli bir adaylık süreci meslek yaşamının daha verimli ve başarııı şekilde devam etmesi açısından önemlidir.

Balc1'ya (2000) göre adaylık süreci bu yönüyle öğretmenlik mesleğinin en önemli ve belirleyici dönemidir. Bir çok araştırma, öğretmenlerin mesleklerinin ilk yıllarında sorunlarla karşılaştıklarını ve özellikle uygulama boyutunda ciddi bir danışmanlık hizmetine gereksinim duyduklarını ortaya koymaktadır (Afşin, 1988; Ekinci, 2010; Korkmaz, 1999; Tellez, 1992; Veenman, 1984; Yalçınkaya, 2002). Bu bakımdan öğretmenlik mesleği açısından özellikle ilk yılı ifade eden adaylık sürecinin özenle tasarlanması ve uygulanması, öğretmen niteliğini geliştirmek açısından oldukça önem taşımaktadır.

Adaylık sürecinde iyi öğretmen modelleri aday öğretmenler için kılavuz görevi görmektedir. Bu nedenle danışman veya mentör olarak adlandırılan öğretmenlerin nitelikli, gelişime açık, işine hakim, iletişimi kuvvetli, yaptığı işten zevk alan ve danışmanlık yapmaya gönüllü kişiler olması sürecin verimliliğini arttıran en önemli etmenlerdendir.

\section{Türkiye'de Aday Öğretmen Yetiştirme Tarihi}

Türkiye'de adaylık eğitiminin 1930'lu yıllara kadar dayandığı görülmektedir. Bu yıllarda İlk ve Orta Tedrisat Muallimlerinin Terfi ve Tecziyeleri Hakkında 1702 Sayılı Kanunda adaylık eğitimi ile ilgili göreve stajyer olarak başlandı̆̆ı, staj süresi sonunda yeterliği kabul edilenlerin talim sicili ve teftiş raporu ile belgelenenlerin öğretmen (muallim) unvanı aldıkları vurgulanmaktadır (Milli Ĕ̆itim Bakanlığı-MEB, 1930). 1943 yılında çıkarılan ve ilkokul kadrolarına ilişkin 4357 sayılı kanunda ise stajyerlik süresinin bir yıldan üç yıla kadar sürebildiği, stajyer başarısının ise oluşturulan bir komisyonca belirlendiği görülmektedir. 1985 yılında ise Devlet Memurları Kanunu'na dayanılarak hazırlanan yönetmelikle stajyer öğretmenlerin Bakanlıkça yetiştirme programının uygulanacağ 1 okullara atanacağı, stajyer öğretmenlerin yetiştirilmesinden okul müdürü ve rehber öğretmenin sorumlu olduğu, stajyerlik süresinin en az bir yıl en fazla iki yıl olacăğ, eğitimde başarılı olanların görev yerlerine atanabileceği belirtilmiştir (MEB, 1985). 1995 yılından çıkarılan yönetmelikle adaylık eğitimi üç aşamalı olarak planlanmıştır. İlk aşama temel eğitim, ikinci aşama hazırlayıcı eğitim, üçüncü ve son aşama uygulamalı eğitimi kapsamaktadır (MEB, 1995). Aday öğretmenlik eğitimi ile ilgili 2014 yılında Milli Eğitim Temel Kanununun (1739 sayılı) 43. Maddesinin altıncı fikrası ile bir düzenlemeye gidilerek aday öğretmenlikte en az 1 yıl fiilen çalışılması gerektiği, performans değerlendirme sonucunda başarılı olanların yazılı ve sözlü sınava girmeye hak kazanacakları belirtilmiş olup iki kez üst üste sınavda başarılı olamayanların memuriyetle ilişiklerinin kesileceği vurgulanmıştır (MEB, 2014). 2016 yllı ile beraber 
aday öğretmenliğe ilişkin yeni bir yönerge hazırlanmış, aday öğretmenlik programı yeniden yapılandırılmaya çalışılmıştır. 2018 yılında Milli Eğitim Bakanlığı'nca yayımlanan "2023 Eğitim Vizyonu" ile eğitim temelden ele alınarak yeniden yapılandırılmaya çalışılmıştır. Ele alınan konulardan birinin de öğretmen yetiştirme ve atama konularında olduğu görülmektedir. Gerçekleştirilmesi planlanan ilk hedef eğitim fakültelerine alınacak öğrencilerin sıralamada üst sıralarda yer alanlar içerisinden seçmektir. İkinci hedef ise sertifikaya dayalı Pedagojik Formasyon uygulaması kaldırılarak yerine öğretmenliğe atanan adaylara yönelik ülke genelinde rahatlıkla ulaşılabilir lisansüstü düzeyde Öğretmenlik Mesleği Uzmanlık Programı uygulanacağı, Yükseköğretim Kurulu (YÖK) ile yapılacak ortak çalışmalar doğrultusunda öğretmenlik uygulamasının merkez alınarak yeniden şekillendirileceği ve bunu ülke genelinde belirlenen ölçütlere uygun eğitim fakültelerinde gerçekleştirileceği, gerekli alt yapının sağlanması ile beraber eğitim fakülteleri MEB'in gereksinimleri doğrultusunda programlarını uygulama ağırlıklı gerçekleştirmesi hedeflenmiştir (MEB, 2018). Planlanan bu değişikliklerle başarılı öğrencilerin öğretmenlik mesleğine kazandırılmanın yanı sıra formasyonu MEB çatısı altında toplayarak öğretmen adaylarının öğretmenlik mesleğine daha hazır ve donanımlı bir şekilde kazandırılmasının hedeflendiği söylenebilir.

\section{Gelişmiş Ülkelerde Aday Öğretmen Yetiştirme Süreci}

Bayrak (1996), eğitim niteliğini bireylerin aldığı eğitimlerle toplumun beklentilerini ne düzeyde karşılayabildiğini belirleyen olgu olarak tanımlar. Eğitimin niteliğinin yüksek olduğu ülkelerde öğretmen yetiştirme ve geliştirmenin önemli bir etmen olduğu görülmektedir. Eğitimde yüksek performans gösteren ülkeler incelendiğinde, yüksek nitelikli lisans eğitimi, doğru planlanmış adaylık eğitimi, yüksek nitelikli mesleklerle aynı düzeyde ücretlendirme, hizmet içi eğitimlere ilişkin doğru planlama, tüm aşamalarda adayın süreç içerisinde olması gibi stratejilerin uygulandığı görülmektedir. Adaylık eğitiminin Avusturya, İsviçre, ABD, Japonya Fransa gibi ülkelerde başarı ile uygulandığı görülmektedir (İlyas, Çoşkun ve Tokluca, 2017).

Gelişmiş ülke aday öğretmenlik süreçleri incelendiğinde ABD'nin Kaliforniya eyaletinde Aday Öğretmen Destek ve Değerlendirme Programı kapsamında 25 yıldır aday öğretmenlere yönelik işe başlama eğitimleri verildiği (Ingersoll, Merrill, ve May, 2014) aynı şekilde ABD'nin New York eyaletinde de göreve seçilenlere yönelik Yeni Öğretmen Programı ile bir sene danışmanlık, beşinci yılın bitimiyle mesleğe devam edilebilmesi için ikinci düzey Uzmanlık Sertifikasına (Professional Certificate) sahip olmaları gerektiği, beş yılda en az üç yıl öğretmenlik yapmak, bir yıl danışman öğretmen ile çalışmak ve yüksek lisans düzeyinde bir eğitim almak koşulu bulunduğu görülmektedir (New York State Education Department-NYSED, 2015).

Finlandiya'nın öğretmen yetiştirme süreci ise daha çok eğitim fakülteleri üzerine kurulmuştur. Tüm yeterliliklerin lisans eğitimi boyunca kazanılması hedeflenir. Öğrenci seçiminde yeterlik sınavı yanında sosyal, sanatsal ve sportif yeterliklerin de dikkate alındığı görülmektedir (İlyas ve diğ., 2017). Güney Kore'de yeni seçilen 
öğretmenlere yönelik altı ay devam eden ve öğretmenliğe ilişkin uygulamaların hizmet içi eğitim kapsamında adaylık eğitiminin verildiği görülmektedir (National Center on Education And The Economy-NCEE, 2016). Kanada'nın Ontario eyaletinde öğretmen olarak atanan tüm adaylara Aday Öğretmen Kurs Programı uygulanarak öğretmenlerin etkili öğretim, öğrenim ve değerlendirme deneyimleri edinmeleri için gerçekleştirilen işe başlama eğitimi uygulanmaktadır (Barrett, Elizabeth, Patrick ve Jordon, 2009). Singapur'da öğretmen olarak seçilen adaylara yönelik üç günlük Yeni Başlayan Öğretmenlerin Uyum Programı yanında iki sene süren Yapılandırılmış Danışmanlık Programı ile uzmanlık rehberlik eğitimi almaları sağlanmaktadır (Darling ve Rothman, 2011 akt., İlyas ve diğ., 2017).

İncelenen tüm ülkelerde aday öğretmen yetiştirme süreci farklı işlese de sonuçta aday öğretmenlerin öğretmenlik mesleğine uyum sağlamalarının hedeflendiği görülmektedir. Bu yolla hem aday öğretmenlerin mesleğe uyum sağlamalarına hem de dolaylı olarak eğitim niteliğinin yükseltilmesine katkıda bulunulmaktadır.

\section{Aday Öğretmen Yetiştirme Programına İlişsinTemel Hususlar}

İlk kez 2016 yılı Şubat döneminde ataması yapılan öğretmenlere yönelik farklı bir uygulama hedeflenerek, öğretmenlerin iş başında yetiştirilmesini sağlayacak bir uygulamaya gidilmiştir. 17.04.2015 tarih ve 29329 sayılı yönetmeliğine dayanılarak hazırlanan 02.03.2016 tarih ve 2456947 sayılı yönerge ile çerçeve program çizilmiş, aday öğretmenlik programının planlanması, uygulanması ve değerlendirilmesi aşamaları ve bu aşamalarda görev alacak personelin görevleri yüzeysel olarak belirlenmiş olup, sürecin çevresel faktörlere göre uyarlanabilen esnek bir program olarak düzenlenmesi amaçlanmıştır (MEB, 2015). Bakanlıkça hazırlanan Yetiştirme Programı'nın aday öğretmenlerin adaylık eğitimine katılacakları kurumlarda, yöneticileri ile danışmanların gözetiminde gerçekleştirileceği vurgulanmıştır. $\mathrm{Bu}$ süreçte aday öğretmenin bağımsız olarak derse giremeyeceği ve aday öğretmene nöbet görevi verilemeyeceği, ancak danışman öğretmen rehberliğinde bu gibi görevleri yerine getirebileceği belirtilmiştir. Aday öğretmenlerin, hazırlanan aday öğretmenlik programı kapsamındaki tüm etkinliklere katılımı zorunlu tutularak, yasal mazeretler nedeniyle yerine getirilemeyen etkinliklerin Bakanlıça belirlenen tarih ve yerde telafi programına katılması zorunlu tutulmuştur (MEB, 2016a).

Yetiştirme programının dört ayak üzerine kurulduğu görülmektedir. $\mathrm{Bu}$ etkinlikler sınıf içinde ve okul içinde gerçekleştirilmesi gereken etkinlikler, öğretmenlik uygulamaları, okul dışında gerçekleştirilmesi gereken etkinlikler ve önceki dönemlerde de uygulanan, Bakanlığın Öğretmen Atama ve Yer Değiştirme Yönetmeliği'nin esas alındığı mevzuat konularını içeren hizmet içi etkinlikleridir. Çalışma programının ise eğitim kurum idarecileri ve danışmanlarca Aday Öğretmen Yetiştirme Programı doğrultusunda hazırlanması hedeflenmiştir. Öğretmen Yetiştirme ve Geliştirme Genel Müdürlüğünce hazırlanan formların eğitim kurumu yönetici ve danışmanlar tarafindan eğitim kurumunun koşullarına göre uyarlanarak uygulanması amaçlanmıştır (MEB, 2016a). 
Aday öğretmen yetiştirme programında görev dağılımı incelendiğinde eğitim kurumları yöneticilerinin görevleri; aday öğretmen çalışma programını danışman öğretmenle birlikte hazırlamak, çalışmaların istenilen nitelikte uygulanması için gerekli önlemleri almak, üst yöneticilerle verilecek görevleri yapmak olarak sıralanmaktadır. Aday öğretmen programının en önemli parçası olan danışman öğretmenin görevleri ise; aday öğretmen programını kurum yöneticisi ile planlamak, program süresince aday öğretmene gerekli desteği sağlamak, aday öğretmenlerin planlanan programa uygun yetişebilmesi için tüm süreçlerde rol model olmak ve süreç içerisinde üst yöneticilerce verilecek görevleri yapmaktır. Aday öğretmenin görevleri; planlanan çalışmaların tümünü yerine getirmek, danışman ve kurum yöneticisinin direktiflerine uymak, planlanan uygulamaları yerine getirirken mevzuata uygun davranmak olarak belirtilmiştir (MEB, 2016a).

Ayrıca, yönergede danışman öğretmenin belirlenmesinde danışman öğretmende aranacak özellikler şu şekilde sıralanmıştır: En az on yıllık bir mesleki deneyime sahip, daha önce danışmanlık yapmış, sosyal ve kültürel yönü kuvvetli, meslekte seçkin bir düzeye ulaşmış, iletişimi kuvvetli ve görevlendirileceği aday öğretmen ile aynı branştan olması esastır. Süre koşulunun sağlanmadığı durumlarda ise çalışma yılı on yıldan daha az olan öğretmenler arasından, aynı branştan öğretmen bulunmaması durumunda ise farklı branşlardanöğretmen görevlendirilebileceği vurgulanmıştır (MEB, 2016b).

Yukarıda ilgili mevzuat ve uygulamalar ışığında çerçevesi sunulmaya çalışılan bu araştırmanın temel amacı özellikle 2016 yılı ile beraber değişen aday öğretmen yetiştirme programını aday ve danışman öğretmen görüşlerine göre değerlendirmektir. 2016 yılında değişen aday öğretmen yetiştirme programı kapsamında aday öğretmenlere yönelik olarak hazırlanan aday öğretmen programının okul içinde ve okul dışında gerçekleştirilmesi istenen etkinlikler ve hizmet içi eğitim çalışmalarından sadece okul içinde ve okul dışında gerçekleştirilecek etkinlikler kapsamında aday ve danışman öğretmenlerin sürece yönelik görüşleri belirlenmeye çalışılmıştır. 2016 yılında uygulamaya geçen ve aday öğretmenlerin hiçbir şekilde derse tek başlarına giremeyeceklerini öngören yönetmelik sadece 2016 Şubat ataması ile atanan aday öğretmenlere uygulanmış daha sonraki atamalarda öğretmen gereksiniminden dolayı süreç öğretmenlerin tek başlarına derse girmeleri ile sonuçlanmıştır.

\section{Araştırmanın Amacı}

Araştırmanın amacı 2016 yılında uygulamaya geçen aday öğretmenlik programının etkililiğini aday ve danışman öğretmen görüşleri yardımıyla belirleyerek programa ilişkin öneriler sunmaktır. Bu genel amaç doğrultusunda aşağıdaki sorulara yanıt aranmıştır:

1. Danışman ve aday öğretmenlerin aday öğretmen yetiştirme programına ilişkin görüşleri nelerdir? 
2. Aday öğretmenlik programına ilişkin aday ve danışman öğretmenlerin görüşlerinde demografik özellikler (yaş, danışmanlık, deneyimi, mezuniyet yıll, cinsiyet, atandığı okul, öğretmenlik deneyimi, hizmet yılı) açısından anlamlı farklar var mıdır?

\section{Yöntem}

Bu başlık altında araştırmada kullanılan model, araştırma verilerinin toplandığı çalışma grubu, veri toplamada kullanılan araçlar ve verilerin analizinde yapılan iş ve işlemler hakkında bilgi verilmiştir.

\section{Araştırma Modeli}

Sosyal bilim araştırmalarında karma yöntem yaklaşımı, belirlenen amaç doğrultusunda iki veya ikiden çok veri toplama yolunun bir araştırma için kullanılması olarak tanımlanmaktadır (Green, Krayder ve Mayer, 2005). Karma yöntem araştırmaları nicel ve nitel tekniklerin üstün taraflarını birleştirerek kullanma kolaylığ 1 sağlamaktadır (Onwuegbuzie ve Leech, 2004, akt., Baki ve Gökçek, 2012). Bu bakımdan çalışmaya kaynak olușturulan veriler karma araştırma yöntemlerinden çeşitleme (triangulation) deseni kullanılarak elde edilmiştir. Birleşik desen ya da eş zamanlı desen olarak da adlandırılmaktadır (Morse ve Niehaus, 2009, akt., Yıldırım ve Şimşek, 2013). Çeşitleme deseni ile hedeflenen iki farklı yöntemi (nicel-nitel) bir arada kullanarak verileri çeșitlendirmek, karşılaştırmak, bütünleştirmek ve farklı, ancak araştırma soruları ile ilk elden verilere ulaşmaktır (Morse, 1991, akt., Yıldırım ve Şimşek, 2013).

Çalışmada nicel veriler tarama modelinde kullanılan ve araştırmacılar tarafından geliştirilen Aday ve Danışman Öğretmen Ölçeği ile nitel veriler ise yarı yapılandırılmış görüşme tekniği ile toplanmıştır. Tarama modelinde amaç, geçmişte veya günümüzde olan bir durumu en doğal biçimiyle sunmaktır (Karasar, 1995). Araştırmalarda yarı yapılandırılmış görüşme tekniğinin kullanılmasındaki amaç belirli düzeyde standartlık yanı sıra esneklik sunmasıdır. Araştırmacı soracağı soruları bir görüşme protokolü şeklinde oluşturur. Bunun yanı sıra araştırmacı planladığı soruların yanında görüşme akışına göre farklı, yan veya alt sorularla görüşmenin akışını etkileyebilir (Ekiz, 2003).

\section{Çalıșma Grubu}

Çalışmanın nicel verilerinin toplandığı çalışma grubu 2015-2016 öğretim yılında Mardin'e bağlı Artuklu, Ömerli, Nusaybin, Yeşilli, Kızıltepe ilçeleri içerisinde yer alan ve tüm kademedeki okullara atanan 267 aday öğretmen oluşturmuş olup, evrenin tümüne ulaşılmaya çalışılmış ve toplam aday öğretmenlerden 207'sine, danışman öğretmenlerden 179'una ulaşı1mıştır. Ulaşılan 207 aday öğretmene ilişkin demografik özellikler Tablo 1'de verilmiştir. 
Tablo 1

Aday Öğretmenlerin Demografik Özellikleri

\begin{tabular}{|c|c|c|c|c|c|}
\hline \multirow[t]{2}{*}{ Mezuniyet } & 2011 ve öncesi & 2012 & 2013 & 2014 & 2015 \\
\hline & 31 & 27 & 41 & 51 & 57 \\
\hline \multirow[t]{2}{*}{ Cinsiyet } & Erkek & & & Kadın & \\
\hline & 84 & & & 123 & \\
\hline \multirow[t]{2}{*}{ Atandığ 1 Okul } & İl Merkezi & İlçe & Merkez Köy & İlçeye Bağ & Köy \\
\hline & 63 & 106 & 17 & 21 & \\
\hline \multirow[t]{2}{*}{ Branş } & $\begin{array}{l}\text { Sinıf } \\
\text { Öğretmeni }\end{array}$ & Matematik & Türkçe & $\begin{array}{l}\text { Okul } \\
\text { Öncesi }\end{array}$ & Diğer \\
\hline & 24 & 11 & 19 & 21 & 132 \\
\hline \multirow{2}{*}{$\begin{array}{l}\text { Öğretmenlik } \\
\text { Deneyimi }\end{array}$} & Yok & Ücretli & Kolej & Dershane & Diğer \\
\hline & 89 & 93 & 4 & 6 & 15 \\
\hline \multirow[t]{2}{*}{ Yaş } & $20-22$ & $23-25$ & $26-28$ & $29-31$ & 32 ve üstü \\
\hline & 17 & 77 & 64 & 23 & 26 \\
\hline
\end{tabular}

Tablo 1 incelendiğinde aday öğretmenlerin büyük bir çoğunluğunun son üç yılda mezun olduğu, kadın sayısının erkek sayısından fazla olduğu, ilçe merkezine daha fazla atama olduğu, aday öğretmenlerin yarısına yakınının ücretli öğretmenlik yaptığı, aday öğretmenlerin çoğunluğunun 20-28 yaş aralığında olduğu görülmüştür. Danışman öğretmenlere ilişkin demografik özellikler Tablo 2'de verilmiştir.

Tablo 2

Danışman Öğretmen Demografik Özellikleri

\begin{tabular}{lllll}
\hline \multirow{2}{*}{ Cinsiyet } & Erkek & \multicolumn{3}{l}{ Kadın } \\
\cline { 2 - 5 } & 119 & 60 & \\
\hline Danışmanlık Deneyimi & Var & Yok & \\
\cline { 2 - 5 } & 37 & & 142 & \\
\hline Hizmet Y1lı & $\mathbf{0 - 9}$ & $\mathbf{1 0 - 1 5}$ & $\mathbf{1 6 - 2 0}$ & $\mathbf{2 1}$ ve üstü \\
\cline { 2 - 5 } & 30 & 89 & 39 & 21 \\
\hline
\end{tabular}

Tablo 2 incelendiğinde danışman öğretmenlerde erkek danışman öğretmen sayısının kadın danışman sayısından fazla olduğu, danışman öğretmenlerin büyük bir çoğunluğunun danışmanlık deneyimlerinin olmadığı, danışman öğretmenlerin çoğunluğunun 10-15 hizmet yılına sahip öğretmenlerden seçildiği görülmüştür.

Araştırmanın nitel verilerinin elde edildiği çalışma grubu ise Mardin Büyükşehir Artuklu ilçesi içerisinde 2016 Şubat atamasıyla aday öğretmenlik sürecine katılan farklı branşlardan (Okul Öncesi Öğretmeni, Sınıf Öğretmeni, Din Kültürü Öğretmeni, Türkçe Öğretmeni, İlköğretim Matematik Öğretmeni, Rehber Öğretmen, Teknoloji Tasarım Öğretmeni, Fen Bilgisi Öğretmeni) 15 aday öğretmen ve 15 danışman öğretmen oluşturmuştur. Veriler kartopu tekniği belirlenen örneklem grubu ile yüz yüze yapılan görüşmelere dayalı olarak toplanmıştır. Öncelikle bir aday öğretmene 
ulaşılmış ve ulaşılan aday öğretmen sayesinde diğer aday ve danışman öğretmenlere ulaşılmıştır. Ulaşılan her aday ve danışman öğretmen sayesinde örneklem grubu genişleyerek büyümüştür. Toplanan veriler içerik analizine dayalı olarak çözümlenmiş ve bulgular temalar yardımıyla sunulmuştur. Tablo 3’te aday öğretmenlere ilişkin demografik bilgiler verilmiştir.

Tablo 3

Aday Öğretmenlerin Demografik Özellikleri

\begin{tabular}{lllllll}
\hline Aday & \multicolumn{2}{l}{ M. Yılı Atandığı Okul } & Cinsiyet & Yaş & Branş & $\begin{array}{l}\text { Öğrt. } \\
\text { Deneyimi }\end{array}$ \\
\hline A1 & 2015 & İlçe Merkezi & Kadın & 23 & Okul Öncesi Öğretmeni & Var \\
\hline A2 & 2015 & İlçe Merkezi & Kadın & 24 & Okul Öncesi Öğretmeni & Var \\
\hline A3 & 2012 & İlçe Merkezi & Kadın & 25 & Sınıf Öğretmeni & Var \\
\hline A4 & 2013 & İlçeyeBağlı Köy & Kadın & 26 & Okul Öncesi Öğretmeni & Var \\
\hline A5 & 2014 & İlçeye Bağlı Köy Erkek & 23 & Sınıf Öğretmeni & Var \\
\hline A6 & 2015 & İl Merkezi & Erkek & 26 & Din Kültürü Öğretmeni & Yok \\
\hline A7 & 2012 & İlçe Merkezi & Erkek & 30 & Sınıf Öğretmeni & Var \\
\hline A8 & 2013 & İlçe Merkezi & Kadın & 24 & Türkçe Öğretmeni & Var \\
\hline A9 & 2014 & İlçe Merkezi & Kadın & 24 & İlköğretim Matematik Öğretmeni Var \\
\hline A10 & 2015 & İlçeye Bağlı Köy Kadın & 23 & Rehber Öğretmen & Yok \\
\hline A11 & 2012 & İlçe Merkezi & Erkek & 30 & Din Kültürü Öğretmeni & Yok \\
\hline A12 & 2015 & $\begin{array}{l}\text { Merkeze Bağlı } \\
\text { Käı Kadın }\end{array}$ & 23 & İlköğretim Matematik Öğretmeni Var \\
\hline A13 & 2014 & $\begin{array}{l}\text { Merkeze Bağlı } \\
\text { Köy }\end{array}$ & Kadın & 24 & Türkçe Öğretmeni & Var \\
\hline A14 & 2012 & İlçeye Bağlı Köy Erkek & 32 & Teknoloji Tasarım Öğretmeni & Yok \\
\hline A15 & 2015 & İlçe Merkezi & Kadın & 23 & Din Kültürü Öğretmeni & Var \\
\hline
\end{tabular}

Aday öğretmenlerin demografik özellikleri incelendiğinde adayların son 4 yıl içinde mezun oldukları, 23-32 yaş aralığında oldukları, onunun kadın beşinin erkek olduğu, sadece dört adayın öğretmenlik deneyiminin olmadığı görülmektedir. Danışman öğretmenlere ilişkin bilgiler Tablo 4'te verilmiştir.

Tablo 4

Danışman Öğretmenlerin Demografik Özellikleri

\begin{tabular}{llllll}
\hline Danışman M. Yılı & $\begin{array}{l}\text { Hizmet } \\
\text { Yılı }\end{array}$ & Cinsiyet & $\begin{array}{l}\text { Danışmanlık } \\
\text { Deneyimi }\end{array}$ & Branş \\
\hline D1 & 2000 & 16 & Kadın & Hayır & Sınıf Öğretmeni \\
\hline D2 & 2004 & 7 & Kadın & Hayır & Okul Öncesi Öğretmeni \\
\hline D3 & 1998 & 18 & Kadın & Hayır & Türkçe Öğretmeni \\
\hline D4 & 2004 & 14 & Erkek & Hayır & İlköğretim Matematik Öğretmeni \\
\hline D5 & 2005 & 11 & Kadın & Hayır & Rehber Öğretmen \\
\hline
\end{tabular}


Tablo 4 (devam)

\begin{tabular}{llllll}
\hline Danışman & M. Yılı & $\begin{array}{l}\text { Hizmet } \\
\text { Yılı }\end{array}$ & Cinsiyet & $\begin{array}{l}\text { Danışmanlık } \\
\text { Deneyimi }\end{array}$ & Branş \\
\hline D6 & 1985 & 27 & Erkek & Evet & Din Kültürü Öğretmeni \\
\hline D7 & 2000 & 16 & Kadın & Evet & Türkçe Öğretmeni \\
\hline D8 & 2002 & 15 & Erkek & Hayır & İlköğretim Matematik Öğretmeni \\
\hline D9 & 2002 & 13 & Kadın & Hayır & Teknoloji Tasarım Öğretmeni \\
\hline D10 & 2001 & 15 & Kadın & Evet & Türkçe Öğretmeni \\
\hline D11 & 1992 & 22 & Kadın & Evet & Fen Bilgisi Öğretmeni \\
\hline D12 & 2006 & 10 & Erkek & Evet & Din Kültürü Öğretmeni \\
\hline D13 & 2002 & 15 & Erkek & Hayır & Müzik Öğretmeni \\
\hline D14 & 2003 & 11 & Erkek & Hayır & Fen Bilgisi Öğretmeni \\
\hline D15 & 2005 & 11 & Erkek & Hayır & Sınıf Öğretmeni \\
\hline
\end{tabular}

Danışman öğretmenlerin demografik özellikleri incelendiğinde danışmanlardan sadece birinin (D2) adaylık programının 10 y1llık hizmet süresini gerektiren maddesine uymadığı görülmektedir.Danışmanların 8'i kadın, 7'si erkek'tir. Danışmanlardan sadece 5'nin danışmanlık deneyimi olduğu görülmektedir.

\section{Veri Toplama Araçları}

Araştırmada iki adet ölçme aracı (aday ve danışman öğretmen ölçeği - yarı yapılandırılmış görüşme formu) kullanılmıştır. Ölçme araçları MEB'nin 2015-2016 öğretim yılında aday öğretmenlere yönelik hazırladığı Aday Öğretmen Yetiştirme Programı temel alınarak araştırmacılar tarafından geliştirilmiştir.

Aday ve danışman öğretmen ölçeği. Nicel verilerin toplanmasında araştırmacılarca geliştirilen aynı doğrultudaki maddelerden oluşan Aday Öğretmen Ölçeği ve Danışman Öğretmen Ölçeği kullanılmıştır. Ölçme aracına açımlayıcı faktör analizi uygulanarak ölçme aracı ölçeklendirilmiştir. Araştırmaya katılan okul müdürü ve öğretmenlerin demografik bilgilerine ulaşmak amacıyla veri toplama arcının ilk bölümüne iki ölçekte de ortak olmak üzere cinsiyet değişkeni belirlenmiş olup, farklı olarak danışman öğretmen ölçeğinde görevdeki hizmet yılı, daha önce danışman öğretmen olarak görevlendirilme durumu, aday öğretmen ölçeğinde ise atandığı okul, yaş, öğretmenlik deneyimi, mezuniyet yılı değişkenlerine yer verilmiştir.

İkinci bölümde yer alan 20 madde üç boyuta (Yeterlik, Planlama-UygulamaDeğerlendirme, Mevzuat) ayrılımıs ve normal dağılım özellikleri incelenmek amacıyla bu maddelere Kolmogrov-Smirnov testi uygulanmıştır. Aday öğretmen ölçeğinin alt boyutlarında test sonuçları şu şekilde belirlenmiştir; yeterlik $(\mathrm{p}>.05)$, planlamauygulama-değerlendirme $(\mathrm{p}>.05)$, mevzuat $(\mathrm{p}>.05)$. Danışman öğretmen ölçeğinin alt boyutlarında ise test sonuçları şu şekilde belirlenmiştir; yeterlik ( $\mathrm{p}>.05)$, planlama-uygulama-değerlendirme $(\mathrm{p}>.05)$, mevzuat $(\mathrm{p}>.05)$. Hem danışman öğretmen ölçeği hem de aday öğretmen ölçeğinin tüm boyutlarında $p$ değerlerinin .05 'ten büyük olması nedeniyle nomalliğin sağlandığı sonucuna ulaşılmış olup, normal dağılım gösteren (Parametrik) analiz teknikleri kullanılmıştır. 
Yarı yapılandırılmış görüşme formu. Nitel verilerin toplanmasında yarıy apılandırılmış görüşme formu kullanılmıştır. Karşılaştırmalı sonuçlara ulaşmak için kullanılan yarı yapılandırılmış görüşme formu, aday öğretmen yetiştirme mevzuatı ve uygulamalar doğrultusunda derlenen sorulardan oluşturulmuştur. Aday öğretmen ve danışman öğretmenler için ayrı ayrı hazırlanan ve 13'er sorudan oluşan yarı yapılandırılmış görüşme formları katılımcılar ile tek tek görüşülerek uygulanmıştır.

Görüşmeler sırasında ses kayıt cihazı kullanılarak olası veri kaybının önüne geçilmeye çalışılmıştır. Katılımcılara görüşme sırasında ses kayıt cihazı kullanılacağı söylenmiş, görüşme sonrası ses kayıtlarının kendilerince dinlenebileceği, istenmesi halinde kayıtların kısmen veya tamamen silinebileceği belirtilmiştir. Böylelikle kayıt cihazının katılımcılar üzerinde oluşturabileceği bask1 ve olumsuzlukların önüne geçilmeye çalışılmıştır. Elde edilen bulguların gerçeği yansıtabilmesi geçerlik, bu bulguların tutarlığı ve tekrar edilebilirliği ise güvenirlik olarak tanımlanmaktadır (Yıldırım ve Şimşek, 2008). Bu araştırmanın geçerlik ve güvenirliğini sağlamak amacıyla; a) içerik analizinde yazıya geçirilmiş her veri araştırmacılarca ayrı ayrı incelenmiş, elde edilen analiz birimlerini karşılaştırılmış ve farklı ifadelerin yer aldığı durumlarda söz konusu ses kayıtları birlikte dinlenerek ilgili analiz birimi yeniden düzenlenmiş, b) elde edilen veriler analiz edildikten sonra katılımcı onayı için öğretmenlerin görüşlerine sunulmuş ve görüşlerini yansıttığına ilişkin onayları alınmış, c) yapılan analizler alanda uzman bir akademisyene incelettirilerek, analiz onayı alınmıştır.

\section{Verilerin Analizi}

Analizler 207 aday öğretmen ölçeği, 179 danışman öğretmen ölçeği ile beraber 15 danışman öğretmen ve 15 aday öğretmen ile yüz yüze gerçekleştirilen görüşmelere dayalı olarak yapılmıştır. Ölçek verilerinin analizi SPSS programı ile gerçekleştirilmiş olup, verilere ilişkin ağırlıklı ortalama, frekans ve standart sapmalar hesaplanmıştır. Araştırmanın ikinci alt problemine ilişkin istatistiksel analizlerde $\alpha=.05$ anlamlılık düzeyinde iki değişkenli veriler için $\mathrm{t}$ testi, ikiden fazla değişkenler için ise Tek Yönlü Varyans (ANOVA) testi uygulanmıştır.

Görüşme verileri içerik analizi yardımıyla çözümlenmiştir. Veri analizi şu aşamalarla gerçekleştirilmiştir; 1-Verileri Kodlama, 2-Kodlara Uygun Tema Oluşturma, 3- Kod ve Temaları Düzenlenme, 4-Tanımlama ve Yorumlama (Yıldırım ve Şimşek, 2008). Aday ve danışman öğretmenlerle gerçekleştirilen görüşmeler sonrası verilen cevaplar doğrultusunda cevapların benzerliğine göre gruplamalar yapılmıştır. $\mathrm{Bu}$ süreçte aday öğretmenlere (A1, A2, ...) şeklinde danışman öğretmenlere ise (D1, D2, ...) şeklinde kodlar verilmiştir. Veriler analiz edildikten sonra aday öğretmenlik programının aday öğretmen ve danışman öğretmen açısından sorunlu olduğu noktalar ve aday öğretmenlik programının yararlı görülen yönleri ve programa yönelik görüş ve öneriler temalar şeklinde belirlenerek sunulmaya çalışılmıştır. 


\section{Bulgular}

Araştırmanın bu bölümünde öncelikle aday ve danışman ölçeklerine ilişkin bulgular daha sonra araştırmanın iki alt problemine ilişkin bulgular ve bu bulgulara ilişkin yorumlar verilmiştir.

\section{Aday ve Danışman Ölçeğine İlişkin Bulgular}

Aday öğretmen ve danışman öğretmenlere yönelik aynı doğrultuda ve 24 maddeden oluşan iki ayrı taslak ölçek geliştirilmiştir. Taslak ölçek ölçülen alanın amacına yönelik üç farklı boyuta (yeterlilik, planlama-uygulama-değerlendirme, mevzuat) ayrılmıştır. Ölçek taslak beş öğretmene uygulanarak maddelerin anlaşılırlık durumları denenmiş ve alınan dönütlere göre maddeler tekrar düzenlenmiştir. Taslak ölçek iki alan uzmanınca incelenmiş ve daha sonra taslak ölçek ile ön uygulama yapılarak, taslak ölçeğe KMO testi ugulanmıştır. Tablo 5'te aday ve danışman öğretmen ölçeğine ilişikin KMO testi sonuçları verilmiştir.

Tablo 5

Aday ve Danışman Öğretmen Ölçeğine İlişkin KMO Testi Sonuçları

\begin{tabular}{lllll}
\hline & KMO Test & Bartlett's Test & df & p \\
\hline Aday Öğretmen & 0.917 & 2036.6 & 231 & .000 \\
\hline Danı̧̧man Öğretmen & 0.907 & 2541.663 & 153 & .000 \\
\hline
\end{tabular}

Tablo 5'te KMO testi bulgularına yer verilmiştir. Danışman öğretmen ölçeği için KMO değeri 907 ve Bartlett testi değeri 2541.663 iken, aday öğretmen ölçeği için KMO değeri .917 ve Bartlett testi değeri 2036.600 olarak bulgulanmıştır. Can (2016) KMO değeri .700 ve üstü değerlerin örneklemde ilişkiyi sağlama noktasında iyi olduğunu vurgular. Böylelikle ölçeğin örneklem açısından iyi olduğunu göstermiştir.

KMO testi sonrası taslak ölçek açımlayıcı faktör analizine tabi tutulmuştur. Analiz sonrası anti-imaj korelasyon matrisinde .50 değeri altında kalan maddeler taslak ölçekten çıkarılarak işlem tekrarlanmıştır. Tablo 6'da aday öğretmen ölçeğine ilişkin açımlayıcı faktör analizi sonuçları paylaşılmıştır.

Tablo 6

Aday Ögretmen Ölçeğine İlişkin Açımlayıcı Faktör Analizi Sonuçları

\begin{tabular}{lccccc}
\hline & & & \multicolumn{4}{c}{$\begin{array}{c}\text { Aday Ölçeği } \\
\text { Madde }\end{array}$} & $\begin{array}{c}\text { Anti-İmaj } \\
\text { Korelasyonu }\end{array}$ & $\begin{array}{c}\text { Communalities } \\
\text { Ortak }\end{array}$ & & Faktör 1 & Faktör 2 & Faktör 3 \\
\cline { 4 - 6 } & & & Yeterlilik & $\begin{array}{c}\text { Planlama-Uygulama- } \\
\text { Değerlendirme }\end{array}$ & Mevzuat \\
\hline M1 & .901 & .678 & .740 & & \\
\hline M2 & .897 & .699 & .764 & & \\
\hline M3 & .957 & .63 & .713 & & \\
\hline M4 & .928 & .615 & .74 & & \\
\hline & & & & &
\end{tabular}


Tablo 6 (devam)

\begin{tabular}{|c|c|c|c|c|c|}
\hline \multirow{3}{*}{ Madde } & \multirow{3}{*}{$\begin{array}{c}\text { Anti-İmaj } \\
\text { Korelasyonu }\end{array}$} & \multirow{3}{*}{$\underset{\text { Ortak }}{\text { Communalities }}$} & \multicolumn{3}{|c|}{ Aday Ölçeği } \\
\hline & & & Faktör 1 & Faktör 2 & Faktör 3 \\
\hline & & & Yeterlilik & $\begin{array}{c}\text { Planlama-Uygulama- } \\
\text { Değerlendirme }\end{array}$ & Mevzuat \\
\hline M5 & .953 & .548 & .759 & & \\
\hline M6 & .929 & .512 & .655 & & \\
\hline M7 & .954 & .599 & .655 & & \\
\hline M8 & .951 & .597 & .709 & & \\
\hline M9 & .969 & .578 & .613 & & \\
\hline M10 & .932 & .527 & .616 & & \\
\hline M11 & .916 & .624 & & .759 & \\
\hline M12 & .845 & .646 & & .608 & \\
\hline M13 & .704 & .549 & & .583 & \\
\hline M14 & .838 & .641 & $.573 *$ & & \\
\hline M15 & .895 & .560 & & .797 & \\
\hline M16 & .858 & .582 & & .678 & \\
\hline M17 & .922 & .51 & & & $.686 *$ \\
\hline M18 & .928 & .557 & & $.543 *$ & \\
\hline M19 & .947 & .556 & & $.632 *$ & \\
\hline M20 & .954 & .566 & & & .655 \\
\hline
\end{tabular}

* Farklı boyutlarda yer alan maddeler.

Tablo 6 incelendiğinde anti-imaj korelasyonunda maddelerin .969 ile .704 değerleri arasında yer aldığı bulgulanmıştır. Açıklanan toplam varyans değerler tablosu incelenmiş özdeğeri 1'den büyük üç faktör saptanmıştır. En az maddeyle en fazla veri toplayacak bir ölçme aracı geliştirmek amaçlandığından dik döndürme yaklaşımlarından Varimax yöntemi seçilmiştir. Döndürülmüş bileşenler tablosu incelenmiş, dört maddenin farklı boyutlarda yer aldığı görülmüştür. Madde alt ölçek korelasyon sonuçları (M14 için $r=.57$, M17 için $r=.68$, M18 için $r=.54$, M19 için $r=.63$ ) bu maddelerin taslak ölçekte belirlenen boyutlarda yer almasını destekleyen sonuçlar verdiğinden dolayı maddelere başta belirlenen boyutlarda yer verilmiştir. Aday öğretmen ölçeğinde üç faktör toplam varyansın \% 56.917'sini karşılamıştır. Tablo 7'de danışman öğretmen ölçeğine ilişkin faktör analizi sonuçlarına yer verilmiştir.

Tablo 7

Danışman Öğretmen Ölçeğine İlişkin Açımlayıcı Faktör Analizi Sonuçları

\begin{tabular}{cccccc}
\hline & & & \multicolumn{3}{c}{ Danışman Ölçeği } \\
\cline { 4 - 6 } Madde & $\begin{array}{c}\text { Anti-İmaj } \\
\text { Korelasyonu }\end{array}$ & $\begin{array}{c}\text { Communalities } \\
\text { Ortak }\end{array}$ & Faktör 1 & Faktör 2 & Faktör 3 \\
\cline { 4 - 6 } & & & Yeterlilik & $\begin{array}{c}\text { Planlama-Uygulama- } \\
\text { Değerlendirme }\end{array}$ & Mevzuat \\
\hline M1 & 0.917 & 0.585 & 0.729 & & \\
\hline M2 & 0.931 & 0.691 & 0.684 & & \\
\hline
\end{tabular}


Tablo 7 (devam)

\begin{tabular}{|c|c|c|c|c|c|}
\hline \multirow[b]{3}{*}{ Madde } & \multirow[b]{3}{*}{$\begin{array}{c}\text { Anti-İmaj } \\
\text { Korelasyonu }\end{array}$} & \multirow{3}{*}{$\underset{\text { Ortak }}{\text { Communalities }}$} & \multicolumn{3}{|c|}{ Danışman Ölçeği } \\
\hline & & & Faktör 1 & Faktör 2 & Faktör 3 \\
\hline & & & Yeterlilik & $\begin{array}{c}\text { Planlama- } \\
\text { Uygulama- } \\
\text { Değerlendirme }\end{array}$ & Mevzuat \\
\hline M3 & 0.938 & 0.589 & 0.716 & & \\
\hline M4 & 0.921 & 0.626 & 0.741 & & \\
\hline M5 & 0.891 & 0.781 & 0.857 & & \\
\hline M6 & 0.930 & 0.667 & 0.592 & & \\
\hline M7 & 0.918 & 0.625 & 0.606 & & \\
\hline M8 & 0.943 & 0.717 & 0.796 & & \\
\hline M9 & 0.893 & 0.689 & 0.731 & & \\
\hline M10 & 0.892 & 0.699 & 0.677 & & \\
\hline M11 & 0.916 & 0.559 & & 0.743 & \\
\hline M12 & 0.919 & 0.571 & & 0.639 & \\
\hline M13 & 0.912 & 0.657 & & 0.732 & \\
\hline M14 & 0.910 & 0.712 & & 0.584 & \\
\hline M15 & 0.958 & 0.516 & & & $0.708^{*}$ \\
\hline M16 & 0.881 & 0.591 & & 0.684 & \\
\hline M17 & 0.898 & 0.576 & & 0.654 & \\
\hline M18 & 0.846 & 0.575 & & $0.532 *$ & \\
\hline M19 & 0.922 & 0.52 & & & 0.886 \\
\hline M20 & 0.901 & 0.636 & & & 0.708 \\
\hline
\end{tabular}

Tablo 7'de anti-imaj korelasyonunda maddeler .958 ile .846 değerleri arasında yer almıştır. Açıklanan toplam varyans değerler tablosu incelenmiş ölçekte özdeğerleri 1'den büyük üç faktör belirlenmiştir. Aday ölçeğinde olduğu gibi dik döndürme yaklaşımlarından Varimax yöntemi seçilmiştir. Döndürülmüş bileşenler tablosu incelenmiş iki maddenin farklı boyutlarda yer aldığı bulgulanmıştır. Madde alt ölçek korelasyon sonuçları (M15 için $r=.70$, M17 için $r=.53$ ) bu maddelerin taslak ölçekte belirlenen boyutlarda yer almasını destekleyen sonuçlar verdiğinden dolayı maddelere başta belirlenen boyutlarda yer verilmiştir. Yapılan istatistiki değerlendirmeler sonucunda uzmanlar arası uyum ve Kapsam Geçerlik İndeksi (Content Validity Index-CVI) değerinin \% 86 olduğu belirlenmiştir. Kapsam Geçerlik İndeksi (CVI) \% 80'den büyük ise madde kapsam geçerliği açısından yeterlidir (Rutherford-Hemming, 2015). Gerçekleştirilen analizler sonrası taslak ölçek 20 maddeden oluşturulmuştur. Danışman ölçeğinde üç faktör toplam varyansın \% 64.607'sini karşılamıştır. Tablo 8'de aday ve danışman ölçeğinin güvenirlik katsayısına ilişkin bilgilere yer verilmiştir. 
Tablo 8

Aday ve Danışman Öğretmen Ölçeğine İlişkin Güvenirlik Katsayısı Sonuçları

\begin{tabular}{lllll}
\hline & \multirow{2}{*}{$\mathbf{n}$} & \multicolumn{3}{c}{ Cronbach Alfa } \\
\cline { 3 - 5 } & & Faktör 1 & Faktör 2 & Faktör 3 \\
\hline Aday Öğretmen & 207 & .916 & .918 & .913 \\
\hline Danı̧̧man Öğretmen & 179 & .941 & .944 & .932 \\
\hline
\end{tabular}

Tablo 8'de aday ve danışman ölçeği güvenirlik sonuçlarına ilişikin bulgulara yer verilmiştir. Analiz sonrası ölçeğin güvenirlik katsayısı tüm boyutlarda Aday Öğretmen Ölçeği için Cronbach Alfa değerlerinin .913 ile .918 arasında, Danışman Ölçeği Cronbach Alfa değerlerinin .932 ile .944 arasında değer aldığı görülmüştür. Bulgulara göre geliştirilen ölçeğin oldukça güvenilir bir ölçek olduğu söylenebilir.

\section{Birinci Alt Probleme İlişkin Bulgular ve Yorum}

Bu bölümde nicel ve nitel verilere ilişkin bulgular ve yorumlar verilmiştir.

Araştırmanın nicel verilerine ilişkin bulgular ve yorum. Bu başlık altında birinci alt probleme ait nicel bulgular aday ve danışman ölçeklerine göre sunulmuştur. Aday ve danışman ölçekleri paralel ölçekler olarak uygulandığından tablolarda bulgular birlikte verilmiştir. Bu bakımdan Tablo 3 'te görüldüğü gibi maddeler her iki katılımcı gruba sorulduğu şekilde birinci tekil kişi (aday öğretmen görüşü) ve üçüncü tekil kişi (danışman öğretmen görüşü) ifade edecek şekilde sunulmuştur.

$\mathrm{Bu}$ bağlamda aday öğretmen yetiştirme programının etkililiğine ilişkin aday ve danışman öğretmen ölçeğinin yeterlik boyutunun bulguları Tablo 9'da verilmiştir.

Tablo 9

Aday Öğretmen Yetiştirme Programının Etkililiğine İlişkin Aday ve Danışman Ögretmen Ölçeği Yeterlik Boyutunun Bulguları

\begin{tabular}{|c|c|c|c|c|}
\hline \multirow{3}{*}{ Maddeler } & \multicolumn{4}{|c|}{ Bulgular } \\
\hline & \multicolumn{2}{|c|}{ Aday } & \multicolumn{2}{|c|}{ Danıșman } \\
\hline & $\overline{\mathrm{X}}$ & SS & $\overline{\mathrm{X}}$ & SS \\
\hline $\begin{array}{l}\text { 1-Aday öğretmenlik uygulamas1 sayesinde ders planlama } \\
\text { sürecinin gereklerini yerine getirecek kadar bilgi edindim/edindi. }\end{array}$ & 3.75 & 1.051 & 4.03 & 1.008 \\
\hline $\begin{array}{l}\text { 2-Aday öğretmenlik uygulaması sayesinde ders materyali } \\
\text { hazırlama ve kullanma yeterliliklerine ulaştım/ulaştı. }\end{array}$ & 3.70 & 1.114 & 4.03 & 0.997 \\
\hline $\begin{array}{l}\text { 3-Aday öğretmenlik uygulaması sayesinde öğrenme ve öğretme } \\
\text { süreci ile ilgili problem alanlarını tanıdım /tanıdı ve çözümüne } \\
\text { yönelik beceri edindim/edindim. }\end{array}$ & 3.79 & 1.005 & 4.07 & 0.872 \\
\hline $\begin{array}{l}\text { 4-Aday öğretmenlik uygulaması sayesinde yönetim süreçleri } \\
\text { hakkında bilgi edindim./edindi. }\end{array}$ & 3.79 & 1.024 & 4.18 & 0.773 \\
\hline
\end{tabular}


Tablo 9 (devam)

\begin{tabular}{|c|c|c|c|}
\hline \multirow{3}{*}{ Maddeler } & \multicolumn{3}{|c|}{ Bulgular } \\
\hline & Aday & \multicolumn{2}{|c|}{ Aday } \\
\hline & $\begin{array}{ll}\bar{X} & \text { SS }\end{array}$ & $\overline{\mathrm{X}}$ & SS \\
\hline $\begin{array}{l}\text { 5-Aday öğretmenlik uygulaması sayesinde okul içi eğitim } \\
\text { faaliyetleri ve sosyal kültürel etkinliklerin uygulanma süreçlerini } \\
\text { tanıdım/tanıd. }\end{array}$ & $3.70 \quad 1.094$ & 4.17 & 0.866 \\
\hline $\begin{array}{l}\text { 6-Aday öğretmenlik uygulaması sayesinde görev yapacağ } 1 / \mathrm{m} \\
\text { eğitim çevresini tanıdım/tanıdı ve sosyal yapısını } \\
\text { öğrendim/öğrendi. }\end{array}$ & 1.286 & 3.88 & 1.198 \\
\hline $\begin{array}{l}\text { 7-Aday öğretmenlik uygulaması sayesinde eğitim ve öğretim } \\
\text { süreçlerinde yer alan paydaş kurumları ve işleyişleri hakkında } \\
\text { bilgi sahibi oldum/oldu. }\end{array}$ & 1.050 & 3.90 & 0.881 \\
\hline $\begin{array}{l}\text { 8-Aday öğretmenlik uygulaması sayesinde mesleki gelişimin ve } \\
\text { eğitim tecrübelerinin paylaşılmasının öneminin farkına } \\
\text { vardım/vardı. }\end{array}$ & $\begin{array}{ll}3.98 & 1.031\end{array}$ & 4.16 & 0.898 \\
\hline $\begin{array}{l}\text { 9-Aday öğretmenlik uygulaması sayesinde eğitim - öğretim } \\
\text { süreçleri ve okul dışı faaliyetler ile ilgili izleme ve değerlendirme } \\
\text { raporu hazırlama becerisi kazandım/kazandı. }\end{array}$ & $3.88 \quad 1.010$ & 3.88 & 1.095 \\
\hline $\begin{array}{l}\text { 10-Aday öğretmen program sonunda programın hedeflediği } \\
\text { yeterliliklere ulaştım/ulaştı. }\end{array}$ & $3.47 \quad 1.325$ & 3.73 & 1.090 \\
\hline Toplam & $\begin{array}{ll}3.75 & 1.099 \\
\end{array}$ & 4.03 & 0.892 \\
\hline
\end{tabular}

Tablo 9 incelendiğinde aday öğretmen ortalamaları birbirine yakın olmakla birlikte en yüksek ortalama "Mesleki gelişim ve eğitim tecrübelerinin paylaşılmasının önemi" maddesinde gerçekleşirken, en düşük ortalama ise "Aday öğretmenlik programı sonrası programın hedeflediği yeterliklere ulaştım” maddesinde gerçekleşmiştir. Danışman öğretmen ortalamalarının aday öğretmen ortalamalarından daha yüksek olması dikkat çekicidir. En yüksek ortalama "Aday öğretmen aday öğretmenlik uygulaması sayesinde yönetim süreçleri hakkında bilgi edindi" maddesinde görülürken, en düşük ortalamanın aday öğretmen görüşünde olduğu gibi "Aday öğretmen, aday öğretmenlik programı sonrası programın hedeflediği yeterliklere ulaştı" maddesinde gerçekleştiği görülmüştür. Bu maddeye yönelik görüşler incelendiğinde aday öğretmenlik sürecinde uygulanan programın aday öğretmene yönelik olarak hedeflenen yeterlikleri kazandırmadığı ve amaca ulaşmadığı söylenebilir. Aday ve danışman öğretmenlerin ölçeğin dokuzuncu maddesine ilişkin ortalamalarının aynı olması aday ve danışman öğretmenlerin rapor hazırlama sürecini birlikte gerçekleştirdiklerinin bir göstergesi sayılabilir. Tablo 10'da öğretmen yetiştirme programının etkililiğine ilişkin aday ve danışman öğretmen ölçeği planlama-uygulama-değerlendirme boyutunun bulguları sunulmuştur. 
Tablo10

Aday Öğretmen Yetişstirme Programının Etkililiğ̈ine İlişkin Aday ve Danışman Öğretmen Ölçeği Planlama-Uygulama-Değerlendirme Boyutuna İlişkin Bulgular ve Yorumlar

\begin{tabular}{|c|c|c|c|c|}
\hline \multirow[t]{3}{*}{ Maddeler } & \multicolumn{4}{|c|}{ Bulgular } \\
\hline & \multicolumn{2}{|l|}{ Aday } & \multicolumn{2}{|c|}{ Danışman } \\
\hline & $\overline{\mathrm{X}}$ & SS & $\overline{\mathrm{X}}$ & SS \\
\hline $\begin{array}{l}\text { 11-Aday öğretmenlik programındaki } r \text { performans } \\
\text { değerlendirmelerinin gelişimimle ilgili fikir vererek } \\
\text { kendimi/adayı geliştirme firsatı doğurduğunu düşünüyorum. }\end{array}$ & 3.47 & 1.325 & 3.93 & 1.074 \\
\hline $\begin{array}{l}\text { 12-Aday öğretmenlik programının hazırlanma süreci beni } \\
\text { tatmin etti. }\end{array}$ & 2.79 & 1.366 & 3.20 & 1.209 \\
\hline $\begin{array}{l}\text { 13-Aday öğretmenlik programının hazırlanma sürecinin her } \\
\text { boyutunda aktif olarak görev aldım/aldı. }\end{array}$ & 3.59 & 1.254 & 3.74 & 1.127 \\
\hline $\begin{array}{l}\text { 14-Aday öğretmenlik programında planlanan çalışmaların } \\
\text { uygulanabilirliğinden memnun kaldım. }\end{array}$ & 3.02 & 1.314 & 3.40 & 1.296 \\
\hline $\begin{array}{l}\text { 15-Bu programın eksiksiz } \\
\text { düşünüyorum. }\end{array}$ & 2.48 & 1.265 & 2.82 & 1.300 \\
\hline $\begin{array}{l}\text { 16-Aday öğretmenlik uygulaması için atanan danışman } \\
\text { öğretmenim süreci yönetebilecek yeterliktedir/ aday } \\
\text { öğrretmen süreci yönetebilcek yeterliğe ulaşt1. }\end{array}$ & 3.87 & 1.339 & 3.82 & 1.181 \\
\hline $\begin{array}{l}\text { 17-Atandığım okul dışındaki bir okulda aday öğretmenlik } \\
\text { programına dâhil olmam/olması, atandığım okuldaki uyum } \\
\text { ve performansımı/performansını etkilemez. }\end{array}$ & 3.00 & 1.395 & 3.08 & 1.365 \\
\hline Toplam & 3.17 & 1.322 & 3.42 & 1.221 \\
\hline
\end{tabular}

Tablo 10 incelendiğinde aday öğretmen görüşlerine ilişkin en yüksek ortalama “Aday öğretmenlik uygulaması için atanan danışman öğretmenim süreci yönetebilecek yeterliktedir" maddesine yönelik görülürken, en düşük ortalama ise "Bu programın eksiksiz bir program olduğunu düşünüyorum" maddesinde gerçekleşmiştir. Danışman öğretmen ortalamalarının aday öğretmen ortalamalarından daha yüksek olduğu saptanmıştır. En yüksek ortalama "Aday öğretmenlik programındaki performans değerlendirmelerinin aday öğretmenin gelişimiyle ilgili fikir vererek adayı geliştirme firsatı doğurduğunu düşünüyorum" maddesine, en düşük ortalama ise aday öğretmen görüşünde olduğu gibi "Bu programın eksiksiz bir program olduğunu düşünüyorum" maddesinde gerçekleşmiştir. Aday öğretmen yetiştirme programının etkililiğine ilişkin aday ve danışman öğretmen ölçeği mevzuat boyutunun bulguları Tablo11'de sunulmuştur. 
Tablo 11

Aday Öğretmen Yetiştirme Programının Etkililiğine İlişkin Aday ve Danışman Öğretmen Ölçeği Mevzuat Boyutu Bulguları ve Yorumları

\begin{tabular}{|c|c|c|c|c|}
\hline \multirow[t]{3}{*}{ Maddeler } & \multicolumn{4}{|c|}{ Bulgular } \\
\hline & \multicolumn{2}{|c|}{ Aday } & \multicolumn{2}{|c|}{ Danıșman } \\
\hline & $\overline{\mathrm{X}}$ & SS & $\overline{\mathrm{X}}$ & SS \\
\hline 18-Aday öğretmenliğe dair mevzuatı biliyorum. & 3.47 & 1.152 & 3.58 & 1.141 \\
\hline $\begin{array}{l}\text { 19-Aday öğretmenliğe dair mevzuatın iyi hazırlandığını } \\
\text { düşünüyorum. }\end{array}$ & 2.89 & 1.230 & 3.07 & 1.188 \\
\hline $\begin{array}{l}\text { 20-Aday öğretmenliğe dair mevzuatın uygulanmasının kolay } \\
\text { olduğunu düşünüyorum. }\end{array}$ & 2.81 & 1.242 & 3.00 & 1.394 \\
\hline Toplam & 3.05 & 1.208 & 3.21 & 1.241 \\
\hline
\end{tabular}

Tablo 11 incelendiğinde aday öğretmen ortalamalarında en yüksek ortalama “Aday öğretmenliğe dair mevzuatı biliyorum” maddesinde, en düşük ortalamanın ise "Aday öğretmenliğe dair mevzuatın uygulanmasının kolay olduğunu düşünüyorum" maddesinde gerçekleştiği görülmektedir. Danışman öğretmen ortalamalarından en yüksek ortalama "Aday öğretmenliğe dair mevzuatı biliyorum" maddesinde, en düşük ortalamanın ise aday öğretmen görüşünde olduğu gibi "Aday öğretmenliğe dair mevzuatın uygulanmasının kolay olduğunu düşünüyorum” maddesinde olduğu belirlenmiştir.

Araştırmanın nitel verilerine ilişkin bulgular ve yorum. Elde edilen veriler üç ana başlık altında ve her başlığa yönelik temalar biçiminde sunulmuştur. Birinci başlık altında aday öğretmenlik programının yararlı görülen temaları, ikinci başlık altında aday öğretmenlik programının sorunlu görülen temaları, üçüncü başlık altında ise aday ve danışman öğretmenlerin programa yönelik görüş ve önerileri sunulmuştur. Son bölümde ise sürece yönelik genel bir değerlendirme yapılmıştır. Temalar verilirken bu temalarla ilişkili aday ve danışman öğretmen görüşlerine de ara ara yer verilmeye çalışılmıştır.

Aday öğretmenlik programının olumlu görülen yönleri. Araştırmanın bu bölümünde aday öğretmenlik programının olumlu görülen yönlerine ilişkin aday ve danışman görüşleri ayrı tablolar olarak sunulmuştur. Bu kapsamda Tablo 12'de aday öğretmenlik programının aday ve danışman öğretmenlerce olumlu görülen temaları sunulmuştur. 


\section{Tablo 12}

Aday Öğretmenlik Programının Aday ve Danışman Öğretmenlerce Olumlu Görülen Temalarl

\begin{tabular}{|c|c|c|}
\hline No & Tema & Görüşler \\
\hline 1 & Tecrübe & 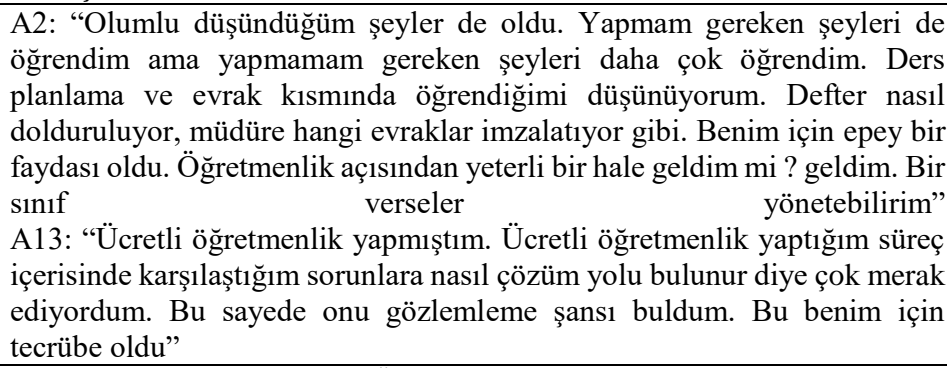 \\
\hline 2 & $\begin{array}{l}\text { Sinıf } \\
\text { Yönetimi }\end{array}$ & $\begin{array}{l}\text { A5: "Bana yararlı oldu. Üniversitede gördüğümüz teorik bilgilerin } \\
\text { uygulanması aşamasında yararı oldu. Benim danışmanım } 20 \text { yıllık } \\
\text { öğretmen olduğu için onun tecrübesinden yararlandım. Özellikle sınıfa } \\
\text { hakim olma konusunda, öğrenci iletişiminde çok yararı oldu" } \\
\text { A13: "Benim danışman öğretmenim çok disiplinli bir hocaydı. Sınıf } \\
\text { yönetimi konusunda çok örnek aldım. Çünkü sıfır şiddet, öğrenciyi } \\
\text { kırmayacak rencide etmeyecek şekilde bir hakimiyet kurmuş ki bu benim } \\
\text { hoşuma çok gitti" }\end{array}$ \\
\hline 3 & İletişim & $\begin{array}{l}\text { A2: "Veli konusunda çok sorun yaşadım. Velilerin istekleri çok farklı. } \\
\text { İletişim konusunda danışmanımdan çok şey öğrendim" }\end{array}$ \\
\hline 4 & Uyum & $\begin{array}{l}\text { A5: "Öğretmenlik mesleğinde tecrübe kazanılması konusunda yararlı } \\
\text { olduğuna inanıyorum" } \\
\text { A7: "Aday öğretmenlik süreci mesleğe yeni başlayan öğretmen adaylarının } \\
\text { uyum sağlaması konusunda katk1 sağlamışır" }\end{array}$ \\
\hline 5 & İdari İşler & $\begin{array}{l}\text { D4: "Ayrıca haftanın bir günü idarede çalışmaları onlar açısından daha iyi } \\
\text { oldu. Belki benden daha iyi ögrenmişlerdir" }\end{array}$ \\
\hline 6 & $\begin{array}{l}\text { Yöntem- } \\
\text { Teknik }\end{array}$ & $\begin{array}{l}\text { A8: "Farklı yöntem ve teknik öğrendim. Hocamın kendine has geliştirdiği } \\
\text { yöntemleri ben de kullanacağım" }\end{array}$ \\
\hline
\end{tabular}

Tablo 12'de danışman ve aday öğretmenlerin aday öğretmenlik sürecine ilişkin olumlu gördükleri temalar ve görüşleri verilmiştir. Danışman ve aday öğretmenlerce adaylık sürecinde olumlu görülen ve aday öğretmene katkısı olduğu düşünülen temel konuların deneyim edinme, sınıf yönetimi, iletişim, uyum, yönetsel işler ve öğretim yöntem ve teknikleri alanlarında gerçekleşen katkılar olarak belirtilmiştir.

Aday ö̆̆retmenlik programına ilişkin sorunlar. Araştırmanın bu bölümünde aday öğretmenlik programına ilşikin aday ve danışman öğretmenlerce sorunlu görülen hususlar ayrı tablolar halinde sunulmuştur. Bu kapsamda aday öğretmenlerin aday öğretmenlik programının sorunlarına ilişkin görüşleri Tablo 13 'te verilmiştir. 
Tablo 13

Aday Öğretmenlerin Aday Öğretmenlik Programının Sorunlarına İlişkin Görüşleri

No Tema Görüşler

1 Form Fazlalı̆̆ 1 A1: “Aday öğretmenlere yönelik tasarlanan bu sistemin faydalı olduğuna inanmıyorum. Çok gereksiz evrak kalabalığı var. Her ders için bir yığın kağıt harcanıyor. Hem danışman hem de aday için iş yükü”

2 Bilgilendirme $\quad$ A1: "Mesleğe yeni başlayan öğretmenler için güzel bir uygulama. İlk Eksiği olması nedeniyle oturması biraz zaman alacak. Bilgilendirme eksik kald1. Bazı durumlarda netlik yoktu. Genel olarak güzel bir uygulama. Öğretmenlik açısından bize çok katkısı olacak. Bu formların nasıl değerlendirileceği konusunda bir fikrim yok"

A5: "Ani olarak uygulandı. Sistem olarak güzel şeyler içeriyor ama Türkiye şartlarına uygun hale getirilmesi gerekiyor. Danışman öğretmenlere 2 günlük bir seminerle bilgilendirme çalışması yapılarak uygulanmaya çalışıldı. Biz onlardan bilgi bekliyoruz onlar bizden bilgi bekliyor. Bu yüzden çok zorluk çektik. Bu eksiklikler giderilirse daha iyi duruma gelebilir.)"

3 Danışman A2: "Genel olarak yapı olarak güzel bir çalışma. Ama kesinlikle Öğretmen yeterli bulmuyorum. Özellikle danışman atanması konusunda bir Yetersizlikleri problem var. Bu yeterliğe sahip mi diye bakılmamış. Mesela benim danışmanım bu yeterliğe sahip bir öğretmen değil. Süreç güzel , düşünce güzel ama uygulama kötü”

A7: "Bu süreçte ne yapmam gerektiğinden çok ne yapmamam gerektiğini öğrendim. Atanan danışman öğretmenlerin kesinlikle aranılan şartlara uygun olduğunu düşünmüyorum. Evet elbette bir şeyle öğrendim ama bu kesinlikle beni tatmin etmedi”

A13: "Danışman olarak atanan hocalar mesleki bakımdan tükenmişlik sendromu yaşamaktadırlar. İlk etapta aşırı kaygı yaşadım. Şu an kendi çabalarımla gayet iyi durumdayım"

\begin{tabular}{|c|c|c|}
\hline 4 & $\begin{array}{l}\text { Danışman } \\
\text { Öğretmen } \\
\text { Eksikliği }\end{array}$ & $\begin{array}{l}\text { A2: "Bulunduğum ilçede yeterince danışman öğretmen olmadığ için } \\
\text { bizi il merkezine gönderdiler. Bu konuda sıkıntı yaşadım. Danışman } \\
\text { öğretmen eksikliğinden kaynaklanan sorunlar vardı. Bu esnetilebilir" }\end{array}$ \\
\hline 5 & $\begin{array}{l}\text { Sürecin } \\
\text { Suistimale Açık } \\
\text { Olması }\end{array}$ & $\begin{array}{l}\text { A6: "Özellikle değerlendirme notlarının danışman ve müdürlerde } \\
\text { olması iyi değil. Çünkü bunun kullanıldığını düşünüyorum. } \\
\text { Değerlendirme daha iyi yapılmalı" }\end{array}$ \\
\hline 6 & $\begin{array}{l}\text { Psikolojik } \\
\text { Etkiler }\end{array}$ & $\begin{array}{l}\text { A14: "Stajyer kavramının öğrenciler tarafindan kullanılması bizi } \\
\text { psikolojik olarak etkiledi" } \\
\text { A13: "Çok saçma bir aday yetiştirme programı. Düzenlenir ve } \\
\text { iyileştirilirse çok daha iyi olur. Aksi takdirde öğretmen olmaya hak } \\
\text { kazananlara stajyer diyerek meslekten soğutabilir" }\end{array}$ \\
\hline
\end{tabular}

(devam ediyor) 
Tablo 13 (devam)

\begin{tabular}{|c|c|c|}
\hline No & Tema & Görüşler \\
\hline 7 & $\begin{array}{l}\text { Ekonomik } \\
\text { Boyut }\end{array}$ & $\begin{array}{l}\text { A15: "Aday öğretmenlik sürecinin iyi fikirlerle yola çıkılmı̧ olmasına } \\
\text { karşın yetersiz olduğunu düşünüyorum. Süreç içinde aday ögretmenin } \\
\text { yaşam şartları düşünülmemiş, adaylı sürecinin } 6 \text { ay süreceği } \\
\text { hesaplanırsa } 6 \text { ay için ev tutma, eşya alma gibi sorunlarla karşı karşıya } \\
\text { kalmaktadır. Ayrıca ek ders ücreti konusunda da sorun var. Okulda } \\
\text { yaklaşık } 40 \text { saat kalıp daha düşük ücret almak ne kadar doğru?" }\end{array}$ \\
\hline 8 & $\begin{array}{l}\text { Uygulamanın } \\
\text { Yapıldığı } \\
\text { Okul }\end{array}$ & $\begin{array}{l}\text { A2: "Atandığım okulla bu okul imkan açısından tam zit. Burada veliden } \\
\text { her şeyi isteyebiliyorsun. Ama orda bunu yapabileceğimi } \\
\text { düşünmüyorum. Mesela bu bende bir soru işareti oluşturdu. Ben oraya } \\
\text { gidince ne yapacağım diye düşünüyorum. Herkes atandığı okula } \\
\text { eşdeğer bir yerde bu sürece katılırsa daha iyi olur diye düşünüyorum" } \\
\text { A8: "Pek iyi bulmadım. Çünkü atandığım okul Yatılı Illköğretim Bölge } \\
\text { Okulu (YİBO) ve ben normal bir okulda bu programa dahil oldum. } \\
\text { Kendi okul yapımla uyuşmadı̆g için çok olumlu görmüyorum. Seneye } \\
\text { tekrar bir uyum sürecine gireceğim. Sınıf içi uygulamalar olarak iyi bir } \\
\text { uygulama" } \\
\text { A5: "Gideceğim okulda karşılaşacağım sorunlar beni biraz } \\
\text { düşündürüyor. Çünkü burası merkezin en iyi okullarından biri. Köy için } \\
\text { kendimi tam olarak donanımlı hissetmiyorum" }\end{array}$ \\
\hline 9 & $\begin{array}{l}\text { Aday } \\
\text { Öğretmen } \\
\text { Öğrenci } \\
\text { İlişkisi }\end{array}$ & $\begin{array}{l}\text { A8: "Okul içi faaliyetler iyiydi. Öğrencilere not verme gibi bir yetkimiz } \\
\text { olmadığ1 için çocukların bizi pek benimsemediğini gördüm. } \\
\text { Öğrencilerin pek umurlarında değildik" } \\
\text { A9: "Tam anlamıyla olduğunu düşünüyorum. Sınıf yönetimi } \\
\text { konusunda eksik kaldığımı düşünüyorum. Sınıfın benim olmamasında } \\
\text { bunun etkisi var" } \\
\text { A13: "Birçok olumlu yanı olduğunu düşünüyorum ama o kadar da etkili } \\
\text { olduğunu düşünmüyorum. Olumsuz yönü ise hep danışman öğretmenin } \\
\text { gölgesinde kalmamız. Okula ve sınıfa karşı bir aidiyet hissetmemek } \\
\text { sorun" }\end{array}$ \\
\hline
\end{tabular}

Tablo 13’te aday öğretmenlerinin aday öğretmenlik sürecine ilişkin sorunlu gördükleri temalar ve görüşleri verilmiştir. Aday öğretmenlerce sorunlu görülen temalar form fazlalığı, bilgilendirme eksikliği, danışman öğretmen yetersizlikleri, adayın durumu, sürecin suistimale açık olması, psikolojik etkiler, ekonomik nedenler, uygulama yapılan okul, aday öğretmen ve öğrenci ilişkileri olarak gerçekleşmiştir. Bu kapsamda danışman öğretmenlerin aday öğretmenlik programının sorunlarına ilişkin görüşleri Tablo 14'te verilmiştir. 
Tablo 14

Aday Öğretmenlik Programının Danışman Öğretmenlerce Sorunlu Görülen Temaları

\begin{tabular}{|c|c|c|}
\hline No & Tema & Görüşler \\
\hline 1 & Form Fazlalığ1 & $\begin{array}{l}\text { D2: "Evrak yükü çok fazla. Zaten o kadar yoğunluk içinde bunlarla } \\
\text { uğraşmak işimizi daha da zorlaştırmaktadır" } \\
\text { D8: "Evrak dışında yararı çok fazla. Azaltılması bile daha yararlı. } \\
\text { İnanın formlar yüzünden gözlemleme bile olumsuz etkileniyor" }\end{array}$ \\
\hline 2 & $\begin{array}{l}\text { Danışman } \\
\text { Öğretmende } \\
\text { Gönüllülük }\end{array}$ & $\begin{array}{l}\text { D7: "Danışman öğretmenler gönülsüz olmalarına rağmen gönüllü } \\
\text { göründüler. İşyükü çok ağırdı. Doldurulan formlar birbirine benzer } \\
\text { ve çok fazla işyükü taşıyordu. Benim açımdan hiç memnun } \\
\text { kalmadığım bir çalışmaydı" } \\
\text { D 11: "Her uygulamada olduğu gibi yine ani ve tepeden inme bir } \\
\text { anlayışla danışman öğretmenler bilgilendirilmeden çok şey istendi. } \\
\text { Ayrıca danışman öğretmenler görevlendirilirken gönüllülük esas } \\
\text { alınmalı diye düşünüyorum" }\end{array}$ \\
\hline 3 & $\begin{array}{l}\text { Bilgilendirme } \\
\text { Eksikliği }\end{array}$ & $\begin{array}{l}\text { D3: "Uygulama güzel fakat altyap1 eksikliği nedeniyle baz1 } \\
\text { aksaklıklar karşımıza ç1ktı. Daha iyi bir bilgilendirmeden sonra } \\
\text { uygulamaya geçilmesi daha iyi olur" }\end{array}$ \\
\hline 4 & Ekonomik Boyut & D6: "O kadar işyükünün karşılıksız bırakılması bence haksızlık" \\
\hline 5 & $\begin{array}{l}\text { Uygulamanın } \\
\text { Yapıldığı Okul }\end{array}$ & $\begin{array}{l}\text { D3: "Güçleştireceğini düşünüyorum. Çünkü benim aday } \\
\text { öğretmenim Yatılı İlköğretim Bölge Okuluna atanmış. Yatılı } \\
\text { İlköğretim Bölge Okulu farklı bir yer. Orda öğrenciler yatılı kalıyor. } \\
\text { Anne babalarından uzak, psikolojik sorunları olanlar olabilir. Bu } \\
\text { konuda zorlanabilir diye düşünüyorum" }\end{array}$ \\
\hline
\end{tabular}

Tablo 14’te danışman öğretmenlerin aday öğretmenlik sürecine ilişkin sorunlu gördükleri temalar ve görüşleri verilmiştir. Danışman ö ğretmenlerce sorunlu görülen temalar form fazlalığı, bilgilendirme eksikliği, danışman öğretmen seçiminde gönüllülük, ekonomik nedenler, uygulama yapılan okul olarak saptanmıştır.

Programa yönelik öneriler. Araştırmanın bu bölümünde aday öğretmenlik programına ilişkin aday ve danışman önerileri ayrı tablolar olarak sunulmuştur. Buna göre aday öğretmenlik programına ilişkin aday öğretmen önerileri Tablo 15'te verilmiştir.

Tablo 15

Aday Öğretmenlik Programına İlişkin Aday Öğretmen Önerileri

\begin{tabular}{cll}
\hline No & Tema & \multicolumn{1}{c}{ Görüşler } \\
\hline 1 & Form-Evrak & $\begin{array}{l}\text { A12: "Formlar işyükü getiriyor çok fazla ne yazacağımızı şaşırıyoruz. } \\
\text { Uygulamaya yönelik çalışmalar yapılırsa daha iyi olur. Biz izleme } \\
\text { sürecini üniversitedeyken almıştık" }\end{array}$ \\
\hline 2 & Bilgilendirme & $\begin{array}{l}\text { A5: "Danışman öğretmenler aday öğretmenlik süreci hakkında daha } \\
\text { fazla bilgilendirilmesi gerekir. Okulda bu konuda bilgi veren bir merci } \\
\text { olması gerekir" }\end{array}$ \\
\hline
\end{tabular}


Tablo 15 (devam)

\begin{tabular}{cll}
\hline No & Tema & \multicolumn{3}{c}{ Görüşler } \\
\hline 3 & $\begin{array}{l}\text { Danışman } \\
\text { Yeterliği }\end{array}$ & $\begin{array}{l}\text { A2: "Danışman öğretmen seçimine dikkat edilmeli. Danışman } \\
\text { öretmenlerin süresinden çok deneyimine bakılmalı. } \\
\text { deneyimsiz öğretmen yerine beş y1llık deneyimli öğretmenler seçilmeli" }\end{array}$ \\
\hline 4 & $\begin{array}{l}\text { Atanılan } \\
\text { Okul }\end{array}$ & $\begin{array}{l}\text { A12: "En büyük eksik bu her halde. Buradaki öğrenciler ben anlatmadan } \\
\text { söylüyor. Atandığım okul köy okulu bu seviyeyi bulacağımı sanmıyorum. } \\
\text { Bence atandığımız okulun eşdeğerinde bir okulda sürece dahil olmamız } \\
\text { gerekir" }\end{array}$ \\
\hline 5 & $\begin{array}{l}\text { Danışman } \\
\text { Seçimi }\end{array}$ & $\begin{array}{l}\text { A15: "Danışman öğretmen seçiminde müdürlerin önerileri göz önünde } \\
\text { bulundurulmalı" }\end{array}$ \\
\hline
\end{tabular}

Tablo $15^{\prime}$ te aday öğretmenlerin aday öğretmenlik sürecine ilişkin önerileri verilmiştir. Aday öğretmenlerin sürece ilişkin önerileri form ve evrak işinin azaltılması, yeterli bilgilendirme yapılması, danışman yeterliklerinin göz önünde bulundurularak danışman seçiminin yapılması, aday öğretmenlerin ek ders konusunda mağdur edilmemeleri (ekonomik), danışman seçiminde okul müdürü önerilerinin göz önünde bulundurulması gerektiği şeklindedir. Buna göre aday öğretmenlik programına ilişkin danışman öğretmen önerileri Tablo 16'da verilmiş̧ir.

\section{Tablo 16}

Aday Öğretmenlik Programına İliş̧kin Danışman Öğretmen Önerileri

\begin{tabular}{|c|c|c|}
\hline No & Tema & Görüşler \\
\hline 1 & Form-Evrak & $\begin{array}{l}\text { D1: "Dosyalar çok fazla. Uygulamaya dönük çalışmaların olması } \\
\text { gerekiyor. Dosya yüzünden bir çok danışman öğretmen sürece dahil } \\
\text { olmak istemiyorlar" }\end{array}$ \\
\hline 2 & $\begin{array}{l}\text { Uygulamaya } \\
\text { Dönük } \\
\text { Etkinlikler }\end{array}$ & $\begin{array}{l}\text { D1: "Dosyalar çok fazla. Uygulamaya dönük çalışmaların olması } \\
\text { gerekiyor. Dosya yüzünden bir çok danışman öğretmen sürece dahil } \\
\text { olmak istemiyor" } \\
\text { D8: "Olumsuz yönü evrak yönü çok fazla. Uygulamaya dönük daha iyi } \\
\text { olur. Olumlu yönü çok çok fazla. Faydası çok fazla" }\end{array}$ \\
\hline 3 & $\begin{array}{l}\text { Danışmanlarda } \\
\text { Gönüllülük }\end{array}$ & $\begin{array}{l}\text { D4: "Danışmanlar gönüllü olarak süreç içinde yer almalı. Böylelikle } \\
\text { verim daha fazla olur" }\end{array}$ \\
\hline 4 & Bilgilendirme & D9: “Biz bizim danışman öğretmenimiz kim bilmiyorduk" \\
\hline 5 & $\begin{array}{l}\text { Üniversite Son } \\
\text { Sinıfta } \\
\text { Uygulama }\end{array}$ & $\begin{array}{l}\text { D8: "Aday öğretmenliğe dair mevzuatın üniversitelerde } \\
\text { uygulanmasının daha faydalı olacağına inanıorum" }\end{array}$ \\
\hline 6 & İş Yoğunluğu & $\begin{array}{l}\text { D7: "Prosedür kısmı daha esnek olsa süreç daha iyi işler. İş yükü fazla } \\
\text { olan öğretmenlere aday öğretmen verilmemeli" }\end{array}$ \\
\hline 7 & Ekonomik & D5: "Danışman öğretmene ek ders ücreti verilmeli" \\
\hline 8 & Branş Farklılı̆g 1 & $\begin{array}{l}\text { D5: "Branş farklılıkları göz önüne alınabilir" } \\
\text { D11: "Hazırlanan formlar Rehberlik ve Okul öncesi branşları için } \\
\text { uygun değildir" }\end{array}$ \\
\hline 9 & $\begin{array}{l}\text { Danışman } \\
\text { Seçimi }\end{array}$ & $\begin{array}{l}\text { D7: "Güzel buluyorum. Artıları da var eksileri de var. Süreç istenilen } \\
\text { gibi yürütüldügünde daha iyi olacağını sanıyorum. Bize külfet } \\
\text { oluşturuyor. 8. Sınıf öğretmenlerine aday verilmesi yanlış bir şey" }\end{array}$ \\
\hline
\end{tabular}


Tablo 16'da danışman öğretmenlerinin aday öğretmenlik sürecine ilişkin önerilerine yer verilmiştir. Danışman öğretmenlerinin sürece yönelik önerileri formevrak işlerinin azaltılması, uygulamaya dönük etkinlikler içermesi, danışmanların gönüllülük esaslı seçilmesi, sürece yönelik yeterli bilgilendirme yapılması, aday öğretmenlik sürecinin üniversite son sınıfta uygulanması gerektiği, danışman öğretmen seçiminde öğretmen yoğunluğunun göz önünde bulundurulması, danışman öğretmenlerin ekonomik olarak desteklenmesi gerektiği, sürece yönelik hazırlanan formların branş farklılıklarına göre hazırlanması gerektiği şeklindedir.

\section{İkinci Alt Probleme İlişkin Bulgular ve Yorum}

$\mathrm{Bu}$ bölümde aday öğretmenlerin aday öğretmenlik programına ilişkin görüşleri ile a) cinsiyet, b) mezuniyet yılı, c) atandığ 1 okul, d) yaş, e) öğretmenlik deneyimi değişkenleri ile danışman öğretmen görüşlerinin a) cinsiyet, b) danışmanlık deneyimi, c) hizmet yılı değişkenleri açısından anlamlı bir fark bulunup bulunmadığına ilişkin bulgulara yer verilmiştir.

Aday öğretmenlerin aday öğretmenlik programına ilişkin görüşleri ile cinsiyet, mezuniyet yılı, atandığı okul, yaş, öğretmenlik deneyimi değişkenleri açısından anlamlı bir fark görülmemiştir. Aynı şekilde danışman öğretmenlerin aday öğretmenlik programına ilişkin görüşleri ile cinsiyet, hizmet yılı değişkenleri açısından anlamlı bir fark görülmemiş olup sadece danışmanlık deneyimi değişkeninin mevzuat boyutunda anlamlı bir fark bulunmuştur. Buna göre danışmanlık deneyimi değişkenine göre danışman öğretmen görüşlerine dair t-testi sonuçları Tablo 17'de verilmiştir.

Tablo 17

Danışmanlık Deneyimi Değişkenine Göre Danışman Öğretmen Görüşlerine Dair tTesti Sonuçlart

\begin{tabular}{lllllll}
\hline Boyutlar & Danışmanlık & $\mathbf{N}$ & $\overline{\boldsymbol{X}}$ & $\mathbf{S}$ & $\mathbf{t}$ & $\mathbf{p}$ \\
\hline Yeterlilik & Evet & 47 & 41.19 & 8.07 & 1.508 & .134 \\
& Hayır & 125 & 39.33 & 6.83 & & \\
\hline Planlama-Uygulama-Değerlendirme & Evet & 47 & 24.57 & 6.96 & 0.857 & .393 \\
& Hayır & 125 & 23.64 & 6.06 & & \\
\hline Mevzuat & Evet & 47 & 10.44 & 2.81 & 2.35 & .020 \\
& Hayır & 125 & 9.28 & 2.89 & & \\
\hline Toplam & Evet & 47 & 76.21 & 15.83 & 1.56 & .120 \\
& Hayır & 125 & 72.27 & 14.31 & & \\
\hline
\end{tabular}

Tablo 17 incelendiğinde tüm boyutlarda (Yeterlik, Planlama-UygulamaDeğerlendirme) ortalamaların danışmanlık deneyimi olan öğretmenlerde daha yüksek olduğu bulunmuştur. Sadece mevzuat boyutunda danışmanlık deneyimi olan öğretmenler ile danışmanlık deneyimi olmayan öğretmenler arasında anlamlı bir fark olduğu bulgulanmıştır. Böylelikle danışmanlık tecrübesine sahip danışman 
öğretmenlerin mevzuat yeterlilik algılarının sahip oldukları deneyimden dolayı daha yüksek olduğu söylenebilir.

\section{Tartışma, Sonuç ve Öneriler}

$\mathrm{Bu}$ çalışmanın amacı 2016 yılında uygulamaya konulan aday öğretmenlik programını aday ve danışman öğretmen görüşleri ışı̆ı̆ında, nicel ve nitel veriler yardımıyla değerlendirmektir. Aday öğretmen yetiştirme programının etkililiğine ilişkin aday ve danışman ölçeklerinin yeterlilik boyutunda aday öğretmenlerin aday ve danışman öğretmenlerce katılıyorum düzeyinde yeterli gördükleri bulgulanmıştır. $\mathrm{Bu}$, aday öğretmen programının aday öğretmenlerden istenilen gereklilikleri yerine getirdiklerinin bir göstergesi sayılabilir. Aday öğretmenlik programının yeterlilik boyutunda aday öğretmenlerce en yüksek ortalamalar mesleki gelişim ve eğitim tecrübelerinin paylaşılması konusunda, danışman öğretmenlerce en yüksek ortalamaların ise aday öğretmenlerin yönetim süreçleri hakkında bilgi edinmeleri konusunda gerçekleştiği görülmüştür. Araştırmanın nitel bulgularında da aday öğretmenlik sürecinin aday ve danışman öğretmenlerce deneyim paylaşımı, sınıf yönetimi, iletişim (öğrenci, veli, okul yönetimi vb.), okul kültürüne uyum, yönetsel işleri öğrenme, öğretim yöntem-tekniklerinin uygulanması konularında aday öğretmenlere katk1 sağladığı görülmüştür. Örneğin, görüşme yapılan aday öğretmenlerden A2 nolu öğretmen adayı dersi planlama, evrak işlerinde çok şey öğrendiğini ifade ederek öğretmenlik mesleği bakımından çok şey öğrendiğini ve bir sınıf verilmesi durumunda yönetebilecek yeterliliğe geldiğini belirtmiştir. Araştırmalar da bu bulguyu destekler nitelikte öğretmen adaylarının mesleki özyeterlik duygusunun güçlenmesinin mesleki başarı, uyum sağlama ve verimlilikte önemli olduğunu ortaya koymaktadır (Anderson, Greene ve Loewen, 1988; Kalaian ve Freeman, 1994; Harlen ve Holroyd, 1997). Bu bakımdan aday ögretmenlerin adaylık sürecini etkili ve verimli şekilde deneyimli bir danışman öğretmen ile birlikte geçirmesinin öğretmenlik mesleğine hazırlanma bakımından özyeterlik duygusunu da güçlendireceğini söylemek mümkündür. Benzer şekilde A5 nolu öğretmen de üniversitede gördüğü kuramsal bilgilerin uygulanması ve sınıf yönetimi bakımından yararlı olduğunu, yirmi yıllık deneyime sahip bir danışman öğretmenin deneyimlerinden oldukça yararlandığını belirtmiştir.

Daha önce yapılan çalışmalarda aday öğretmenlerin bu konularda sıkıntı yaşadıkları görülmektedir. Örneğin Köse'nin (2016) çalışmasında aday öğretmenler her ne kadar başarılı bir lisans eğitimi geçirmiş olsalar da aday öğretmene deneyim kazandırma konusunda yetersiz kalındığını, Özonay'ın (2004) araştırma bulgularında ise adaylık eğitim programının içindeki konuların aday öğretmen gereksinimlerini karşılayacak ölçüde kapsamlı olmadığını, programda konulara uygun öğretim yöntem ve tekniklerin kullanılmadığı, eğitim araçlarından yararlanılmadığı, Solak'ın (1999) çalışmasında da göreve yeni başlayan öğretmenlerin sınıf yönetimi, öğrencilerle sağlıklı iletişim kurma, velilerle işbirliği yapma, mesleğe ve okula uyum sağlama gibi alanlarda güçlük çektiklerini belirtmişlerdir. Yeni aday öğretmenlik programının bu sorunları çözme noktasında başarılı olduğu söylenebilir. Ulubey'in (2017) 
çalışmasında aday öğretmenlik sürecinin mesleğe uyum sağlamada, mesleki bilgi ve becerilerin gelişmesinde, sınıfa ve okula uyum sağlamada katkısı olduğu, Kozikoğlu ve Soyalp'in (2016) çalışma sonuçlarında aday öğretmenlik uygulaması kapsamındaki sınıf içi gerçekleştirilen gözlemlerin yararlı olduğu, danışman deneyiminde yararlanmayı ve mesleki yönden gelişmi desteklediği, Tunçbilek ve Tünay’ın (2017) araştırma sonuçlarında aday öğretmenlerin süreç sonunda sorumluluk ve kendini geliştirme becerisini kazanma yanında sınıf yönetimi, iletişim, teknloji becerisi kazanma konularında da aday öğretmenlere katkı sağlayacağı, Gül, Türkmen ve Aksel'in (2017) çalışma bulgularında da aday öğretmenlerin sınıf ve okul ortamına uyum sağlama, ders planlama, sınav soruları hazırlama, öğrenci ilişkileri ve işlemleri hakkında deneyim kazanma, heyecanını atma gibi mesleki kazanımlar elde ettikleri tespit saptanmıştır.

Araştırmada önemli bulgulardan biri de danışman öğretmenlerin aday öğretmenleri, yeterlik boyutunun tüm maddelerinde aday öğretmenlerden daha yüksek düzeyde yeterli görmeleridir. Buradan hareketle danışman öğretmen görüşü esas alındığında, yeterlik boyutunda aday öğretmenlerin kendilerini yeterli hissettikleri düzeyin daha üstünde bir yeterliğe sahip oldukları sonucuna varılabilir. Bunun önemli nedenlerinden birini de öz güven ve mesleki yeterliğe ilişkin sorunlar olduğu belirtilebilir. Hoy ve Spero'nun (2005) öğretmenlik mesleğinin ilk yıllarındaki özyeterliğe ilişkin değişimi ele aldığı çalışmasında, özellikle lisans döneminde mesleğe hazır olma bakımından özyeterlik duygusunun oldukça yüksek olduğunu ancak, aday öğretmen olarak mesleğe girişle birlikte öz yeterliliğin belirgin şekilde bir düşüş gösterdiğini saptamışlardır. Araştırmalarındaki önemli bulgulardan biri de özyeterlik düzeyinin mesleğin ilk yılında aldıkları danışmanlık desteğine bağlı olarak değiştiğini ortaya koymaktadır (Sakız, Ekinci, ve Sarıçam, 2019). Dolayısıyla etkili bir danışmanlık desteğinin aday öğretmenlerde mesleki bakımdan öz yeterlilik duygusunu güçlendirdiği görülmektedir. Tunçbilek ve Tünay’ın (2017) araştırma sonuçlarında öğretmenlerin diğer katılımcılara (aday öğretmen, idareci, maarif müfettişi, danışman, il-ilçe yöneticisi) oranla aday öğretmenlik süreci sonunda gelişime daha az olumlu bakmakta, beceri kazanma noktasında aday öğretmenlerin yönetici ve danışman öğretmenlere göre beklentilerinin daha düşük olduğu görülmüştür. $\mathrm{Bu}$ durumun genel anlamda aday öğretmenlerin uygulama sürecindeki gelişimlerini yeterince değerlendiremediklerini ve aldıkları danışmanlığın etkililiğine ilişkin bir fikir verdiğini söylenebilir.

Aday öğretmenlik programı uygulama öncesi bölgesel farklılıkların düşünülmemesi ve çok kısa bir süre içerisinde uygulanması beraberinde bir takım sorunlara yol açmıştır. Öncelikle, aday ve danışman öğretmenlere yönelik bilgilendirme eksikliği olmak üzere, danışman öğretmen seçimi, okul seçimi gibi konularda zorluk çekilse de süreç içinde bu sorunlara ilişkin çözümler üretilmeye çalışılmıştır. Kozikoğlu ve Soyalp'in (2016) çalışma bulgularında da danışman öğretmenlerin programa ilişkin yeterli düzeyde bilgi sahibi olmadıkları, Köse'nin (2016) araştırma bulgularında ise programın uygulama sürecinde karşılaşılan problemlerin temelinde bilgilendirmede yaşanan eksikliklerin olduğu sonucuna 
varılmıştır. Bu bulgular, aday öğretmenlik programlarının uygulanmadan önce geniş bir zamana yayılmış bir bilgilendirme ve tanıtım sürecinden geçmesi gerektiğini ortaya koymaktadır.

Aday ve danışman öğretmen ölçeklerinin planlama-uygulama-değerlendirme boyutunda aday öğretmen görüşlerinin kararsızım düzeyinde, danışman öğretmen görüşlerinin katıllyorum düzeyinde olduğu görülmüştür. En yüksek ortalamaların aday öğretmenlerde "Danışman öğretmenim süreci yönetebilecek yeterliktedir", danı̧̧man öğretmenlerde ise "Aday öğretmenlik programındaki performans değerlendirmenin adayı geliştirme firsatı doğurduğunu düşünüyorum" maddelerinde görülürken en düşük ortalamaların ise aday ve danışman öğretmen görüşlerinde benzer şekilde "Aday öğretmenlik programının eksiksiz bir program olduğunu düşünüyorum" maddesinde gerçekleştiği görülmüştür. Her ne kadar aday öğretmen görüşlerinde en yüksek ortalama "Danışman öğretmenim süreci yönetebilecek yeterliliktedir" maddesinde görülmesine karşın araştırmanın nitel bulgularında bu yeterlilikte bulunmayan danışman öğretmenlerin görevlendirildiği de görülmüştür. Bu sorunun en büyük nedeni, danışman öğretmenlikte gönüllüllük aranmaması ve özellikle kırsal bölgelerde danışman öğretmen koşullarını taşıyan öğretmenlerin az sayıda olması veya bulunmaması gösterilebilir. Araştırma bulgularında bazı aday öğretmenlerin bulundukları ilçelerde öğretmen görevlendirilememesi nedeniyle farklı ilçelerdeki okullarda aday öğretmenlik programına alındıkları görülmüştür. Balkar ve Şahin'in (2014) çalı̧̧malarında danışmanın (mentörün) sahip olması gereken özellikler; güven verici, işbirlikçi olma, empati ve iletişim becerilerine sahip olması şeklinde belirlenmiştir. Bu özelliklerin bir kısmı kişilik özellikleri ile ilgili olmakla birlikte, deneyim ve mesleki yeterliğin danışman niteliklerinde önemli bir yer tuttuğunu söylemek olanaklıdır. Bu doğrultuda gerekli önlemlerin alınması yoluyla aday öğretmen yetiştirme sürecinin niteliğini artırmak artırılabilir.

Çalışmanın nitel bulgularında aday öğretmenlik programının aday ve danışman öğretmenlerce eksik veya sorunlu görülen noktalardan biri de çok fazla form doldurulmasıdır. Ulubey'in (2017) çalışma sonuçlarında aday öğretmenlik programı kapsamında doldurulan formların çok fazla ve işlevsiz olduğu, sürekli aynı formların doldurulduğu, aynı şekilde Köse'nin (2016) çalışma sonuçlarında aday öğretmenlik süreci ile ilgili doldurulan formların çok fazla olduğu ve bunun danışman öğretmen ve yöneticilerin iş yükünü arttırdığı, Gül ve diğ.'nin (2017) çalışma bulgularında da gereğinden fazla kırtasiyeciliğin aday öğretmenlik programının aksayan yönlerinden biri olduğu sonucuna varılmıştır.

Aday öğretmenlik programına "Adayın atandığı okul dışındaki bir okulda öğretmenlik programına dahil olması adayın atandığı okuldaki uyum ve performansını etkilemez" maddesine yönelik aday ve danışman öğretmen görüşlerinin de kararsızım düzeyinde olduğu görülmüştür. Çalışmanın nitel bulgularında da aday öğretmenin atandığı okul dışındaki bir ilde veya okulda aday öğretmenlik programına dahil olması hem aday hem de danışman öğretmenlerce olumsuz bir uygulama olarak görülmüştür. Köse'nin (2016) araştırmasında da aday öğretmenlerin uygulamayı 
gerçekleştirikleri eğitim kurumlarında, öğrenci özelliklerinin ve okul olanaklarının üst düzey olması nedeniyle daha düşük düzeyde imkanlara sahip eğitim kurumlarına atanan öğretmenlerin uyum noktasında sorun yaşayabilecekleri, Nayır ve Kuru-Çetin (2016) çalışma bulgularında aday öğretmenlerin atandıkları okullarda aday öğretmenlik programını yürütmeleri gerektiği, Sarıkaya, Samancı ve Yılar (2017)'ın araştırma sonuçlarında öğretmenlerin büyük bir çoğunluğunun aday öğretmen programını atamanın yapıldığı okulda tamamlaması gerektiği görüşüne sahip olmasına karşın, adaylık eğitimini kendi okulunda almanın öğrenci ve veli nezdinde prestij kaybına neden olabileceği gibi olumsuz durumların söz konusu olabileceği düşünülmektedir. Türkiye koşulları göz önünde bulundurulduğunda özellikle kırsal, birleştirilmiş sınıf eğitiminin yapıldığı okullar ile Doğu ve Güneydoğu Anadolu Bölgeleri'ndeki öğretmen açı̆̆ı nedeniyle danışman öğretmen görevlendirme konuları aday öğretmenlerin atandıkları yerde aday öğretmenlik programına dahil olmaları, süreçte karşılaşabilecekleri en büyük engel olarak görülebilir.

Aday öğretmenliğe ilişkin veri toplama aracının mevzuat boyutunda aday ve danışman öğretmenlerin kararsızım düzeyinde görüş bildirdikleri görülmüştür. En düşük ortalamanın aday ve danışman öğretmenlerce "Aday öğretmenliğe dair mevzuatın uygulanmasının kolay olduğunu düşünüyorum” maddesinde olduğu görülmüştür. Çalışmanın nitel bulguları gözönüne alındığında aday öğretmenlik programının branş farkı gözetilmeksizin hazırlanması, aday öğretmenlik programı hakkında yeteri kadar bilgilendirme yapılmaması, çok fazla ve benzer formların doldurulması, danışman öğretmenlerin seçimi ve yetiştirilmeleri, kısacası aday öğretmenlik programının bir alt yapı oluşturulmadan ve çok kısa bir süre içerisinde uygulanması gibi hususlardan dolayı, hazırlanan aday öğretmenlik programı mevzuatının amaca hizmet etmede yetersiz kaldığı söylenebilir.

Aday öğretmenler açısından diğer bir sorun da aday veya stajyer kavramının aday öğretmen üzerinde oluşturduğu psikolojik etkilerdir. Aday öğretmenler, aday veya stajyer kavramının öğrenciler üzerinde farklı bir alg1 oluşturduğunu ve öğrencilerin aday öğretmenleri, öğretmen gibi görmemelerinden kaynaklı sorunlar yaşadıklarını dile getirmişlerdir. Bu sorun mesleğin ilk yıllarında öğretmenlerin karşılaştıkları önemli sorunlardan biri olarak dikkat çekmektedir. Bu sürecin doğru bir şekilde yönetilememesi öğretmen adaylarının meslekten soğumasına veya mesleğe, öğrencilere ve diğer paydaşlara yönelik olumsuz bakış açıları geliştirmesine neden olabilir. Aslan, Dayığlu-Öcal'ın (2012), çalışmasında da aday öğretmenlerin mesleğin ilk yıllarında bazı psikolojik sorunlar yaşabildiğini ve bunun öğretmenliği bırakma noktasına kadar ulaşabildiğini bulguladıkları görülmektedir. Sarıkaya ve diğ.'nin (2017) araştırma sonuçlarında, aday öğretmenlik sürecinin adayları psikolojik yönden öğretmenlik mesleğine uyum sağlamalarına yardımcı olduğu sonucuna ulaşmışlardır. Bunun yanı sıra aday öğretmenlere lisans döneminde gerçekleştirilen (okul deneyimi-öğretmenlik uygulaması) uygulamalar ile karıştırılarak aday öğretmenlere lisans öğrencisi gözüyle bakıldı̆̆ı; öğrencilerin aday öğretmenleri abi veya abla olarak tanımlandıkları belirtilmiştir. Bu durumun da aday öğretmenler üzerinde olumsuz etki oluşturduğunu söylemek olanaklıdır. 
Çalışmanın nitel bulgularına göre aday öğretmenlik programının hem aday hem de danışman öğretmenlerce eksik görülen noktalarından biri uygulamada aday öğretmenlere ek ders ücreti ödenmemesi, danışman öğretmenlere yönelik ise herhangi bir maddi veya manevi getirisinin olmamasıdır. Aday öğretmenlerin danışman öğretmenler ile beraber derse girmelerinden dolayı ek ders almaları uygun görülmemiş, danışman öğretmenlere da bu görev için herhangi bir ek ücret verilmemiştir. Sarıkaya ve diğ.'nin (2017) araştırmasında da sürecin ekonomik bir getirisinin olmaması, bazı danışman öğretmenlerin sürece gereken önemi vermemesine, bazı danışman öğretmenlerin ise adaylık programını yük olarak algılamasına sebebiyet verdiği tespit edilmiştir. Süreç içerisinde aday öğretmenlerin ek ders ücreti, danışman öğretmenlerin danışmanlık ücreti alması uygulamanın verimliliğini arttıran bir etmen olarak düşünülebilir.

Aday öğretmenlerin cinsiyet, mezuniyet yıll, atandığı okul, yaş, öğretmenlik deneyimi değişkenleri ile aday öğretmen görüşleri arasında anlamlı bir fark görülmemiştir. Danışman öğretmenlerin cinsiyet ve hizmet yılı değişkenleri ile danışman görüşleri arasında anlamlı bir fark görülmezken, danışmanlık deneyimi açsından mevzuat boyutunda anlamlı bir fark görülmüştür. Mevzuat boyutunda danışmanlık deneyimi olan öğretmenlerin mevzuat yeterlilik algılarının daha yüksek olduğu bulgulanmıştır. Aynı şekilde Gökulu'nun (2016) araştırma bulgularında cinsiyet ve branş değişkenleri açısından anlamlı fark görülmezken, mezuniyet y1lı değişkeni açısından yeni mezun olan ile daha önce (2010'dan önce) mezun olan aday öğretmen görüşleri arasında anlamlı bir fark görülmüş olup yeni mezun öğretmen görüşlerinin daha olumlu olduğu görülmüştür.

Aday öğretmenlik programı yapılan görüşmeler 1şığında değerlendirildiğinde programın öğretmenliğe yeni atanmış adaylar için çok yararlı bir program olduğu yönündedir. Özellikle lisans düzeyinde kuramsal olarak alınan derslerin uygulamada nasıl uygulamaya geçtiğini görmek açısından adaylara önemli kazanımlar sağladığını söylemek olanaklıdır. Aday öğretmenlerin okul kültürünü tanımaları, öğretim yöntem ve tekniklerinin nasıl kullanıldığı, öğrenci-veli iletişiminin nasıl sağlandığı, yönetsel işlerin nasıl yürüdüğü konularında elde ettikleri kazanımlardan başlıcaları olarak belirtilebilir. Benzer şekilde Gökulu'nun (2017) çalışmasında aday öğretmenlerin aday öğretmenlik sürecine ilişkin olumlu görüşlere sahip olduğu sonucuna ulaşılmış ve Önder'in (2018) çalışma bulgularında da aynı şekilde aday öğretmenlik programı çalışmalarının genellikle katkı sağlayıcı nitelikte olduğu görülmüştür.

Araştırmanın sonuçları 1şığında programın uygulanması aday öğretmenlerin yetiştirilmesine ve sürecin daha verimli şekilde uygulanmasına katkı sağlaması için şu öneriler belirtilebilir:

1. Danışman öğretmen ölçütleri sadece hizmet süresi üzerinden yürütülmemeli, danışman öğretmenlerde yeterlik aranmalıdır. Danışman öğretmenler okul müdürlerinin önerisiyle seçilebilir. 
2. Danışman öğretmenlik çekici duruma getirilmelidir. Araştırma sonuçlarından da anlaşılacağı üzere sürecin ekonomik boyutu öncelikli olmak üzere farklı getirilerinin (kademe ilerlemesi, başarı belgesi, ... vb.) olması gerekmektedir.

3. Evrak sayısı azaltılarak uygulamaya dönük çalışmalar arttırılmalıdır.

4. Aday öğretmenlik süreci aday öğretmen, danışman ve okul müdürlerine ayrıntılı bir şekilde uzmanlarca hizmet içi eğitimlerle anlatılmalıdır.

5. Bulunduğu yerde uygun danışman öğretmen sağlanamayan aday öğretmene en yakın yerlerde yolluk ve yevmiyeleri verilerek danışman sağlanmalıdır.

6. Aday öğretmenlerin aday öğretmenlik programını atandıkları okullara eş değer okullarda geçirmeleri verimliliğini arttırabilir.

7. Hazırlanan aday öğretmenlik programında branş farklılıkları göz önünde bulundurulmalıdir.

8. Danışman öğretmenlere danışmanlık ücreti, aday öğretmenlere ek ders ücreti verilmesi aday öğretmenlik programının verimliliğini arttırabilir.

\section{Kaynakça}

Afşin, F. N. (1988). Stajyer öğretmenlerin meslekle ilgili sorunlarl ve çözüm yolları. (Yayımlanmamış yüksek lisans tezi). Ankara Üniversitesi Sosyal Bilimler Enstitüsü, Ankara.

Anderson, R., Greene, M., and Loewen, P. (1988). Relationships among teachers' and students' thinking skills, sense of efficacy, and student achievement. Alberta Journal of Educational Research, 34(2), 148-165.

Aslan, B., and Dayığlu-Öcal, S. D. (2012). A case study on mentoring in a teacher development program. Journal of Education and Future, 2, 31-48.

Baki, A. ve Gökçek, T. (2012). Karma yöntem araştırmalarına genel bir bakış. Elektronik Sosyal Bilimler Dergisi, 11(42), 1-21.

Balc1, A. (2000). Örgütsel sosyalleşme: Kuram, strateji ve taktikler. Ankara: PegemA Yayıncilik

Balkar, B. ve Şahin, S. (2014). Aday öğretmenlere yönelik mentörlük programının uygulanmasına ilişkin eğitimcilerin görüşleri. International Journal of Social Science, (29), 83-100. doi: 10.9761/JASSS2547

Barrett, S., Elizabeth, R., Patrick S.and Jordan S. (2009). The hidden curriculum of a teacher induction program: Ontario teacher educators' perspectives. Canadian Journal of Education, 32(4), 677-702.

Bayrak, S. (1996). Eğitim ve kalite ilişkisi. Türk Yurdu Dergisi, 17(123), 40-46. 
Can, A. (2016). SPSS ile bilimsel araştırma sürecinde nicel veri analizi. Ankara: Pegem Akademi.

Ekinci, A. (2010). Aday öğretmenlerin iş başında yetiştirilmesinde okul müdürlerinin rolü. Dicle Üniversitesi Ziya Gökalp Eğitim Fakültesi Dergisi, 15, 63-77.

Ekiz, D. (2003). Eğitimde araştırma yöntem ve metotlarına giriş. Ankara. Anı Yayınc1lik.

Gökulu, A. (2017). Aday öğretmenlerin Türkiye'deki aday öğretmenlik eğitim süreci ile ilgili görüşleri. International Journal Social and Education Research, 3(1), 111-123. http://dergipark.gov.tr//ijsser adresinden edinimiştir.

Green, J. C., Krayder, H., and Mayer, E. (2005). Combining qualitative and quantitative methods in social inquiry. In B. Somekh \& C. Lewin (Eds.), Research methods in social sciences (pp. 275-282). London: Sage.

Gül, İ., Türkmen, F. ve Aksel, N. (2017). Aday öğretmen görüşlerine göre aday öğretmen yetiştirme sürecinin değerlendirilmesi. Hitit Üniversitesi Sosyal Bilimler Enstitüsü Dergisi, 10(1), 365-388. doi: 10.17218/hititsosbil.289419

Harlen, W., and Holroyd, C. (1997). Primary teachers's understanding of concepts of science impact on confidence and teaching. International Journal of Science Education, 19(1), 93-105.

Hoy, W. A., and Spero, B. R. (2005). Changes in teacher efficacy during the early years of teaching: A comparison of four measures. Teaching and Teacher Education, 21, 343-356.

Ingersoll, R., Merrill, L., and May, H. (2014). What are the effects of education and preparation on beginning teacher attrition? (Research Report No. RR-82). Retrieved from http://www.cpre.org/sites/default/files/researchreport/2018_prepeffects2014.pdf

Ilk ve Orta Tedrisat Muallimlerinin Terfi Ve Tecziyeleri Hakkında Kanun. (1930). T. C. Resmi Gazete, 153, 29 Haziran 1930.

Illkokul Öğretmenlerinin Kadrolarına, Terfi, Taltif ve Cezalandırllmalarına ve Bu Öğretmenler İçin Teşkil Edilecek Sağllk ve İçtimai Yardım Sandiğ ile Yapı Sandı̆̆ına ve Öğretmenlerin Alacaklarına Dair Kanun. (1943). T. C. Resmi Gazete, 5308, 19 Ocak 1943.

İlyas, İ. E., Çoşkun, İ. ve Tokluca, D. (2017). Türkiye'de aday ögretmen yetiştirme modeli izleme ve değerlendirme. İstanbul: Seta Yayınları.

Kalaian, H. A., and Freeman, D. J. (1994). Gender differences self-confidence and educational beliefs among secondary candidates. Teaching and Teacher Education, 10(6), 647-658.

Karasar, N. (1995). Bilimsel araştırma yöntemi. Ankara: 3A Araştırma Eğitim Danışmanlık. 
Korkmaz, S. (1999). Göreve yeni başlayan ögretmenlerin mesleğe uyum sorunları (Yayımlanmamış yüksek lisans tezi). Kocaeli Üniversitesi Sosyal Bilimler Enstitüsü, Kocaeli.

Kozikoğlu, İ. ve Soyalp, H. (2018). Aday öğretmenlerin, danışman öğretmenlerin ve okul yöneticilerinin aday öğretmen yetiştirme programına yönelik görüşlerinin incelenmesi. Hacettepe Üniversitesi Ë̆itim Fakültesi Dergisi, 33(4), 934-952. doi: 10.16986/HUJE.2018037027

Köse, A. (2016). Okul yöneticilerinin görüşlerine göre aday öğretmen yetiştirmesürecinin değerlendirilmesi. Abant İzzet Baysal Üniversitesi Ĕgitim Fakültes Dergisi, 16(3), 924-944.

Milli Eğitim Bakanlığı (1985). Milli eğitim gençlik ve spor bakanlığına bağlı okul ve kurumlara stajyer olarak atanan öğretmenlerin stajyerlik işlemlerine ilişkin yönerge. Tebliğler Dergisi, (2186). http://tebligler.meb.gov.tr/index.php/tuemsayilar/viewcategory/49-1985 adresinden edinilmiştir.

Milli Eğitim Bakanlığı (1995). Millî eğitim bakanlığı aday memurların yetiştirilmelerine ilişkin yönetmelik. Tebliğler Dergisi, (2423). http://tebligler.meb.gov.tr/index.php/tuem-sayilar/viewcategory/59-1995 adresinden edinilmiş̧ir.

Milli Eğitim Bakanlığı (2016a). Aday öğretmen yetiştirme programı. https://mus.meb.gov.tr/meb_iys_dosyalar/2016_02/25020621_adayretmenyetiti rmesreci.pdf adresinden edinilmiştir.

Milli Eğitim Bakanlığı (2016b). Aday öğretmen yetiştirme sürecine ilişkin yönerge. https://erzincan.meb.gov.tr/meb_iys_dosyalar/2016_03/03113624_02052358_y nerge.pdf adresinden edinilmiştir.

Milli Eğitim Bakanlığı (2018). 2023 Eğitim vizyonu. http://2023vizyonu.meb.gov.tr/doc/2023_EGITIM_VIZYONU.pdf adresinden edinilmiştir.

Millı̂ Eğitim Bakanlığı Öğretmen Atama ve Yer Değiştirme Yönetmeliği (2015). T. C. Resmi Gazete, 29329, 17 Nisan 2015.

National Center on Education And The Economy (2016). I South Kore: Teacher and principal quality. Retrieved from http://ncee.org/what-we-do/center-oninternational-education-benchmarking/top-performing-countries/south-koreaoverview/

Nayır, F. ve Kuru-Çetin, S. (2016, Temmuz). Muğla ilinde aday öğretmenlerin danışman öğretmenlik uygulamasına ilişkin görüşleri. $2^{\text {nd }}$ International Conference on Lifelong Education and Leadership for all kongresinde sunulan sözlü bildiri, Liepaja University, Liepaja-Latvia.

New York State Education Department (2015). Professional certificate. Retrieved from http://www.highered.nysed.gov/tcert/certificate/typesofcerts/prof.html 
Önder, E. (2018). Aday öğretmen görüşlerine göre aday öğretmen yetiştirme programı. Kuram Ve Uygulamada Ĕ̈itim Yönetimi, 24(1), 143-189.

Özonay, İ. Z. (2004, Temmuz). Öğretmenlerin adaylık eğitimi programının değerlendirilmesi. XIII. Ulusal eğitim bilimleri kurultayı, İnönü Üniversitesi, Eğitim Fakültesi, Malatya.

Rutherford-Hemming, T. (2015). Determining content validity and reporting a content validity index for simulation scenarios. Nursing Education Perspectives, 36, 389-393.

Sakız, H., Ekinci, A., and Sarıçam, H. (2019). Teachers' perceptions of their school managers' skills and their own self-efficacy levels. International Journal of Leadership in Education. doi: 10.1080/13603124.2018.1562094

Sarıkaya, İ., Samancı, O. ve Yılar, Ö. (2017). Aday öğretmen yetiştirme sürecinin aday ve danışman görüşleri kapsamında değerlendirilmesi: Bir karma yöntem çalışması. Gazi Üniversitesi Gazi Eğitim Fakültesi Dergisi, 37(3), 939-989.

Solak, İ. (1999). Aday öğretmenlerin yetiştirilmelerine ilişskin yönetmelikte öngörüllenuygulamall eğitimin değerlendirilmesi (Malatya Örneği), (Yayımlanmamış yüksek lisans tezi). İnönü Üniversitesi Sosyal Bilimler Enstitüsü, Malatya.

Tellez, K. (1992). Mentors by choice, not design: help-seeking by beginning teachers, Journal of Teacher Education, 43(3), 214-221.

Tunçbilek, M. M. ve Tünay, T. (2017). MEB Aday öğretmen yetiştirme süreci uygulamasının ilgili tarafların bakış açısıyla değerlendirilmesi. Elektronik Sosyal Bilimler Dergisi, 16(61), 412-427.

Ulubey, Ö. (2017). Aday yetiştirme programının değerlendirmesi. Hacettepe Üniversitesi Eğitim Fakültesi Dergisi, 33(2), 480-502. doi: 10.16986/HUJE.2017031014

Veenman, S. (1984). Perceived problems of beginning teachers. Review of Educational Research, 54(2), 143-178.

Yalçınkaya, M. (2002). Yeni öğretmen ve teftiş. Milli Eğitim Dergisi, (153-154). https://dhgm.meb.gov.tr/yayimlar/dergiler/Milli_Egitim_Dergisi/153154/yalcinkaya.htm adresinden edinilmiştir.

Yıldırım, A. ve Şimşek H. (2013). Sosyal bilimlerde nitel araştırma yöntemleri. Ankara: Seçkin Yayıncılık. 


\title{
Evaluation of the Effectiveness of Candidate Teacher Training Program with the Vievs of Candidates and Advisors $^{1}$
}

\begin{tabular}{cccc}
\hline ARTICLE TYPE & Received Date & Accepted Date & Published Date \\
Research Article & 10.02 .2018 & 10.04 .2019 & 10.04 .2019 \\
\hline
\end{tabular}

Abdurrahman Ekinci (iD ${ }^{2}$, Serdar Bozan (iD) ${ }^{3}$ and Halis Sakız (iD ${ }^{4}$

Mardin Artuklu University

\begin{abstract}
The aim of this study is to investigate the effectiveness of teacher training program from the perspectives of candidate and advisor teachers and to make recommendations based on these perspectives. The sample consisted of 207 candidate teachers and 179 advisor teachers who were assigned to kindergarten, primary, pre-secondary and secondary schools in six districts of Mardin, Turkey during the 2015-2016 education year. Data were collected using mixed research methods involving Candidate and Advisor Teacher Scales for quantitative data and interview schedules for qualitative data. Statistical analysis of quantitative data was performed using t-test and ANOVA. The qualitative data were analyzed via content analysis. The quantitative findings are mostly at the undecided level regarding the effectiveness of the candidate teachers' program; and that the advisors are satisfied with the program. Findings from qualitative data indicated that the program was very useful for newly appointed candidate teachers.
\end{abstract}

Keywords: Candidate teacher, advisor teacher, candidate teacher program.

${ }^{1}$ The qualitative findings of this study were presented in the VIII. Presented at the Audit Congress.

${ }^{2}$ Prof. PhD., Faculty of Letters, Department of Educational Sciences, E-mail: a.ekinci74@yahoo.com, https://orcid.org/0000-0002-1545-1379

${ }^{3}$ Corresponding Author: Inst., Mardin Midyat Vocational School, Department of Child Development, Email: s.bozan@ @otmail.com, https://orcid.org/0000-0002-1677-4727

${ }^{4}$ Assoc. Prof., Faculty of Letters, Department of Psychology, E-mail: halissakiz@artuklu.edu.tr, https://orcid.org/0000-0003-2406-1011 


\section{Purpose and Significance}

It is safe to argue that one of the most important factors that influence the quality of the education system is the quality of teachers. With this in mind, it is especially important to keep the proficiency of teachers up-to-date and provide them with relevant in-service training to enhance their knowledge and skills. Particularly when teachers are at the process of candidacy, which forms the first years of the profession, providing them with opportunities to merge their theoretical knowledge with practice is important.

According to Balc1 (2000), the candidacy process is the most critical period of the teaching profession in that it has a determinative value for the upcoming years. Many researchers show that teachers face problems in their first years of their profession and they need serious supervision especially in applying their knowledge within the field (Afşin, 1988; Ekinci, 2010; Korkmaz, 1999; Tellez, 1992; Veenman, 1984; Yalçınkaya, 2002). In this respect, the design and implementation of the process of teacher assignment, which takes place in the first year, especially in terms of the teaching profession, is very important in terms of improving the quality of teachers.

In the process of teacher assignment, experienced and competent teachers serve as models and guides for prospective teachers. For this reason, it is important to increase the efficiency of this process because when teachers or mentors are qualified, open to development, occupational, strong, and willing to offer guidance, the benefit of candidate teachers also increases.

It is seen that teacher training and development is an important factor in countries whose education system is described as a high level and quality system. When countries with high performance and quality in education are examined, it is seen that strategies such as high-quality pre-service teacher training, well-designed start-up training (nomination training), similar remuneration for other respectable professions, well-designed in-service training, curriculum studies, evaluation and active participation in decision-making processes are applied. In the process of candidacy or teacher preparation, it is seen that almost all elements that make up a good education system with high teacher quality are embedded in the systems of countries such as Australia, France, Greece, Israel, Italy, Japan, South Korea, Switzerland, New Zealand and USA (İlyas, Çoşkun and Tokluca, 2017).

In Turkey, for the first time in February 2016, a different teacher training program was initiated by the Ministry of National Education for newly assigned teachers in order to make sure that teachers are trained and prepared well before their actual practice. The framework program has been drawn up with the directive no: 2456947 dated 02.03.2016 and prepared on the basis of the teacher assignment and relocation regulation dated 17.04.2015 and numbered 29329. The program included stages such as planning, implementation and evaluation; tasks to be carried out by candidate and experienced teachers; and a flexible nature that can be adapted to various environmental contexts (Ministry of National Education [Milli Eğitim 
Bakanlığ1-MEB], 2015). It has been emphasized that the Training Program prepared by the Ministry will be carried out under the responsibility of the administrators of the educational institution and the advisor teachers in the institutions where candidate teachers are assigned.

Up to date, a detailed investigation regarding the efficacy of the teacher training program has not been carried out. Therefore, the aim of this research is to investigate the effectiveness of the candidate teaching program implemented in 2016 in the light of candidate and advisor teacher opinions and offer recommendations for policy and practice. In response to this general objective, answers to the following questions were sought;

1. What are the opinions of the advisor and candidate teachers on the candidate teacher training program?

2. Are there significant differences in terms of demographic characteristics (age, counseling, experience etc.) in the opinions of candidate and advisor teachers regarding the candidate teaching program?

\section{Method}

The data that constitute the source of the study were obtained by using the triangulation pattern from the mixed research methods. It is also referred to as a combined pattern or simultaneous pattern (Morse and Niehaus, 2009, as cited in Yıldırım and Şimşek, 2013). Using the purposeful qualitative and quantitative methods of the variation pattern, we diversified, compared and integrated the data obtained different but directly relevant data (Morse, 1991, as cited in Y1ldirım and Şimşek, 2013). In the study, the scale used in the quantitative screening model and the qualitative data were analyzed and obtained by the semi-structured interview technique. The screening model is a research model aimed at describing the past or present as if there is an existing situation. The event, individual or the object that are subject of the investigation are defined as if they existed within their own conditions (Karasar, 1995). The semi-structured interview technique seems to be more appropriate for educational science research with a certain level of standardization and at the same time flexibility. In this technique, the researcher prepares an interview protocol that includes questions that she/he plans to ask in advance. On the contrary, the researcher may influence the course of the interview with different, side or sub questions according to the flow of the interview besides the planned questions (Ekiz, 2003).

In the 2015-2016 academic year, the study group consisted of 207 candidate teachers who were assigned to 179 advisor teachers at kindergarten, primary, presecondary and secondary schools within the boundaries of Artuklu, K1z1ltepe, Ömerli, Yeşilli, Nusaybin, Mardin.

The qualitative data of the study were obtained from counselors and teachers belonging to various branches such as Class Teacher, Religious Culture Teacher, 
Turkish Teacher, Elementary Mathematics Teacher, Guidance Teacher, Technology Design Teacher, and Science. Teachers were smiled via snowball sampling. Data were collected based on face-to-face interviews conducted with teachers and counselors. The collected data were analyzed based on content analysis. Findings were presented under several crystallised themes.

\section{Results}

There were no significant differences between candidate teachers' gender, year of graduation, school, age, teacher experience variables based on candidate teachers' opinions. While there was no significant difference between advisor teachers' gender and service years variables and advisor opinions, there was a significant difference in the legislative dimension in terms of the supervision experience. It has been found that teachers who have experience of supervision at the legislative level have higher perceptions of legislative competence. It is possible to say that these findings are suitable to be taken as a positive evaluation in terms of relevant legislation.

It has been seen that candidate and advisor teachers are considered to be adequate at the level of agree in terms of the adequacy of candidate and advisor scales regarding the effectiveness of the candidate teacher training program. This can be considered as a demonstration that the candidate teacher program fulfills the requirements of the candidate teachers.

\section{Discussion and Conclusions}

Having evaluated the candidate teaching program in the light of interviews, it can be inferred from data that the program is a very useful one for newly appointed candidates. It is also possible to say that the program provides several advantages to the candidates in terms of observing how the theoretically taken courses at the undergraduate level pass on to the students in terms of practice. Some of the main acquisitions of teacher candidates can be described as following: being acquainted with the school culture, learning how teaching methods and techniques are used, how student-parent communication is provided and how administrative tasks work.

On the other hand, immediate implementation of the candidate teaching program has also brought some problems during its practice. We can argue that the program can be more useful when difficulties are solved that are experienced in the process information provision, advisor assignment, advisor briefing and school selection. It is possible to say that the application of the program in the light of the above mentioned problems and suggestions will contribute to the training of the candidate teachers and lead to a more efficient implementation of the process. 